\title{
Regulation of tumor cell plasticity by the androgen receptor in prostate cancer
}

\author{
Jennifer L Bishop ${ }^{1,2, *}$, Alastair Davies ${ }^{1,2, *}$, Kirsi Ketola ${ }^{1,2}$ and Amina Zoubeidi ${ }^{1,2}$ \\ ${ }^{1}$ The Vancouver Prostate Centre, 2660 Oak Street, Vancouver, British Columbia, Canada V6H-3Z6 \\ ${ }^{2}$ Department of Urologic Sciences, University of British Columbia, Vancouver, British Columbia, Canada \\ *(J L Bishop and A Davies contributed equally to this work)
}

Correspondence should be addressed

to A Zoubeidi

Email

azoubeidi@

prostatecentre.com

\begin{abstract}
Prostate cancer ( $\mathrm{PCa}$ ) has become the most common form of cancer in men in the developed world, and it ranks second in cancer-related deaths. Men that succumb to PCa have a disease that is resistant to hormonal therapies that suppress androgen receptor (AR) signaling, which plays a central role in tumor development and progression. Although AR continues to be a clinically relevant therapeutic target in $\mathrm{PCa}$, selection pressures imposed by androgendeprivation therapies promote the emergence of heterogeneous cell populations within tumors that dictate the severity of disease. This cellular plasticity, which is induced by androgen deprivation, is the focus of this review. More specifically, we address the emergence of cancer stem-like cells, epithelial-mesenchymal or myeloid plasticity, and neuroendocrine transdifferentiation as well as evidence that demonstrates how each is regulated by the AR. Importantly, because all of these cell phenotypes are associated with aggressive $\mathrm{PCa}$, we examine novel therapeutic approaches for targeting therapy-induced cellular plasticity as a way of preventing PCa progression.
\end{abstract}

\section{Key Words \\ - prostate \\ - androgen receptor \\ - endocrine therapy resistance}

\section{Introduction}

Prostate cancer ( $\mathrm{PCa}$ ) has become the most common form of cancer in men in the developed world, and it ranks second in cancer-related deaths, with the vast majority of these fatalities resulting from metastatic disease (Siegel et al. 2014). Advanced PCa is initially treated with androgen deprivation therapy (ADT), a key therapeutic approach that is based on the central role that androgens play in tumor development and growth (Heidenreich et al. 2014). Although it is widely used and was initially highly effective, ADT uniformly leads to the development of castration-resistant PCa (CRPC), an aggressive and usually fatal cancer state that continues to progress despite treatment. The recent development of therapeutics that block androgen receptor (AR) activity, such as abiraterone and enzalutamide, has greatly enhanced clinical management and extended the survival of CRPC patients in both the pre- and the postchemotherapy setting (de Bono et al. 2011, Ryan et al. 2013, Beer \& Tombal 2014). Nonetheless, advanced PCa remains incurable because resistance rapidly emerges via the reactivation of the AR and/or alternative adaptive mechanisms (Joseph et al. 2013). Tumor cell plasticity induced by androgen deprivation may play a principal role in treatment resistance and disease progression, and it potentially provides a new opportunity for therapeutic intervention.

Although the precise mechanism that governs the development of CRPC has yet to be fully realized, CRPC

Published by Bioscientifica Ltd 
arises when cancer cells maintain AR signaling in the absence of normal levels of ligand or when they shed their dependence on the AR entirely by hijacking alternative growth and survival pathways. Several mechanisms for explaining CRPC progression have been proposed, including: altered functionality of the AR because of genetic alteration, which results in either hypersensitive (Visakorpi et al. 1995, Waltering et al. 2009), promiscuous (Fujimoto et al. 2007), or constitutively activated (Dehm et al. 2008) states; the intratumoral synthesis of androgens (Locke et al. 2008); and altered growth factor and/or microenvironment signaling (Lai et al. 2009, Sun et al. 2012, Lubik et al. 2013, Yang et al. 2014). Despite concerted efforts to develop pharmacological agents that are capable of suppressing AR signaling, progression is inevitable. Selection pressures imposed by therapy promote genomic rearrangements, alter inflammatory and immune responses, and change the structure of chromatin, and they thereby allow PCa cells to adapt to a plastic phenotype/genotype (Yu et al. 2010, Urbanucci et al. 2012, Sharma et al. 2013). In this review, we focus on therapyinduced cellular plasticity, specifically the emergence of cancer stem-like cells (CSCs), epithelial-mesenchymal or myeloid plasticity, and neuroendocrine transdifferentiation, which may contribute to disease progression. A clear understanding of these processes will help guide novel therapeutic strategies that could enhance the efficacy of clinically utilized anti-androgen therapy to cure, or at least delay, PCa.

\section{Prostate tumor plasticity: CSCs}

Cancer stem cell theory proposes that cancer cell populations have a hierarchical developmental structure, and only a fraction of tumor cells - the CSCs - can drive tumor growth and disease progression, perhaps through therapy resistance and metastasis. This framework has been based on genetic tracing studies that showed that cancers are composed of a heterogeneous population of cells that not only possess the capacity for self-renewal but also have extremely aggressive metastatic ability and heightened resistance to conventional radio- and chemotherapies (Chen et al. 2012, Driessens et al. 2012, Schepers et al. 2012). Accumulating evidence suggests that PCa contains a rare and distinct population of CSCs that are responsible for tumor formation and are similar to those CSCs found in other cancers (Bonnet \& Dick 1997, Al-Hajj et al. 2003, Collins et al. 2005, Visvader \& Lindeman 2008). To illustrate this point, PCa patients who harbor an embryonic stem cell (ESC) gene expression signature have poor survival outcomes and highly metastatic tumors (Markert et al. 2011). Prospective prostate CSCs have been isolated from cell lines and dissociated primary tumors based on the expression of cell surface markers, which usually include CD44 in combination with a variety of other markers, such as $S C A 1, C D 133, A L D H$, and/or $\alpha 2 \beta 1$ integrin. For example, $\mathrm{CD}_{4} 4^{+}$cells fractionated from PCa cell lines and patientderived xenografts have been shown to be enriched in tumorigenic and metastatic progenitor cells as compared to isogenic $C D 44^{-}$cells (Patrawala et al. 2006). Moreover, as few as $100 \mathrm{CD} 44^{+} / C D 24^{-}$cells derived from the LNCaP cell line demonstrated tumor-forming abilities when they were transplanted into NOD/SCID mice (Hurt et al. 2008). Finally, prospective CSCs have been isolated from primary human PCa cell lines based on the expression of $C D 44^{+} / C D 133^{+} / \alpha 2 \beta 1^{h i}$, and these cells were able to self-renew and regenerate phenotypically mixed populations in vitro (Collins et al. 2005, Wei et al. 2007).

As is evident from these previous studies, a lack of consensus exists with respect to the marker expression and phenotype of the prostate CSC subpopulation. This has been complicated by an incomplete and contradictory understanding of the cellular hierarchy within the normal prostate. Studies by van Leenders et al. have begun to dissect the different prostate cell populations based on their unique cytokeratin expression patterns (Schalken \& van Leenders 2003). However, it remains difficult to determine whether a cancer cell of origin is a stem cell, a multipotent progenitor, or of a more differentiated progeny because of the lack of in situ markers and our inability to isolate pure cell populations. The discordance between stem cell markers in cell lines and clinical specimens has further hampered our ability to quantify CSCs in human specimens (Hoogland et al. 2014). Despite these technical challenges, there is evidence to suggest that the expansion of intermediate epithelial stem cells causes PCa (van Leenders et al. 2000). For example, the activation of oncogenic signaling pathways (e.g., AKT) in $S C A 1^{+}$murine stem/progenitor cells were shown to give rise to high-grade prostatic intraepithelial neoplasia (PIN) lesions following an 8-week incubation (Xin et al. 2005). Early studies demonstrated that basal stem cells are capable of tumor induction in renal grafting models (Goldstein et al. 2010, Taylor et al. 2012). More recently, however, elegant lineage-marking experiments in multiple mouse models have directly implicated Nkx3.1expressing luminal stem cells as the favored cells of origin (Karthaus et al. 2014, Wang et al. 2014).

Published by Bioscientifica Ltd 
All of these studies fit the simple assumption that normal prostate stem cells acquire genetic and/or epigenetic alterations to transform into CSCs, which drive tumor progression. The picture became more complicated when the current doctrine regarding unidirectional normal and neoplastic stem cell hierarchies was scrutinized. Three large independent studies revealed that tumor cells display considerable plasticity; that is, differentiated, post-mitotic cells are able to ascend the cellular hierarchy and re-enter the CSC state. The paradigmshifting work of Gupta et al. demonstrated that breast cancer cell populations can interconvert between phenotypic states. These initial findings indicated that CSCs can arise de novo from non-stem-like cells and that this process of de-differentiation can occur continually during the development of a tumor (Gupta et al. 2011). Additional work by the Weinberg group identified that contextual signals from the microenvironment, specifically $T G F \beta$ coupled to the activation of $Z E B 1$, regulate the conversions from non-CSC to CSC states (Chaffer et al. 2011, 2013). Finally, a study by Flavahan et al. (2013) revealed that glioblastoma cells can de-differentiate into CSCs under the pressure of certain stressors, such as glucose deprivation. A similar phenomenon has been described in $\mathrm{PCa}$, wherein cellular stress caused by anti-androgen therapy induced LNCaP and PC3 cells to convert to a CSC state (Tang et al. 2009). Together, these studies represent an important landmark. It is now clear that transformed cells retain some degree of phenotypic plasticity, and in response to appropriate stimuli, they can reactivate stem cell-associated self-renewal programs to drive advanced disease.

\section{$A R$ as a regulator of CSCs}

There is accumulating evidence that ADT yields an expansion of CSCs, which suggests that the loss of canonical AR activity may be a potential inducer of the CSC state and of non-CSC-to-CSC plasticity. In both human xenograft and transgenic TRAMP models, the expression of stem cell markers increased dramatically post-ADT (Tang et al. 2009, Seiler et al. 2013), whereas PCa patients who received ADT were found to harbor an expanded $C D 133^{+}$CSC population (Lee et al. 2013a). Keeping with these findings, several recent studies found that some prostate CSC subpopulations express low levels of AR and are resistant to castration. Cells isolated on the expression of $C D 44^{+} / C D 133^{+} / \alpha 2 \beta 1^{\text {hi }}$ were found to be $\mathrm{AR}^{-}$(Collins et al. 2005), and $\mathrm{CD} 44^{+} / \mathrm{AR}^{-}$cells from patient-derived xenografts co-expressed stem-cell associated genes ( $\mathrm{Gu}$ et al. 2007). Additionally, in the BM18 xenograft model, preexisting CSCs, which are $\mathrm{AR}^{\text {lo }}$ and co-express $A L D H 1 A 1$ and/or NANOG, were selected by castration and could reinitiate CRPC tumor growth (Germann et al. 2012). Most notably, Qin et al. (2012) discovered a cell population with low expression of prostate specific antigen (PSA), a direct target gene of AR, within high-grade prostate tumors that exhibited a heightened self-renewal capacity. These cells also expressed CSC-associated markers, such as CD44, integrin $\alpha 2$, and $A L D H 1 A 1$, exhibited high clonogenic potential, and possessed tumor-propagating capacity. The $\mathrm{ALDH}^{+} / \mathrm{CD} 44^{+} / \alpha 2 \beta 1^{+} \mathrm{CSC}$ subpopulation could be prospectively purified in $P S A^{-1 / 0}$ cells, which indicates that low AR expression and/or activity may increase the CSC population (Qin et al. 2012).

Although these clinical data are supportive of the implication that AR suppression is a modulator of CSC plasticity, they are not entirely sufficient to verify this suggestion. Fortuitously, studies of ESCs have provided more extensive evidence for an involvement of AR in regulating a stem-like state. It has been demonstrated that AR signaling suppresses ESC self-renewal capacity (Chang et al. 2006), and during ESC differentiation, AR levels continue to increase in order to 'tip the balance' from selfrenewal to differentiation (Sauter et al. 2005). Similarly, in PCa, AR-negative cell lines have an increased ability to form non-adherent spheroids, which are a surrogate measure of self-renewal capacity (Li et al. 2008). More recent work using siRNA or the anti-androgen bicalutamide to suppress AR in PCa cell lines has resulted in enhanced spheroid formation (Lee et al. 2013a), which provides further support for the suggestion that AR inhibits self-renewal capacity. In a reciprocal set of experiments, overexpression of AR within the $C D 133^{+}$ CSC population isolated from LNCaP and C4-2 cell lines dramatically reduced spheroid formation (Lee et al. 2013a). Together, these studies establish AR as a major regulator of the CSC phenotype in PCa.

Although we believe that a model in which aberrant AR signaling can enhance cellular plasticity is sound, the mechanism remains poorly understood. One possible mechanistic explanation for the association between the CSC phenotype and AR is its ability to directly regulate stem cell transcription factors, including SOX2, NANOG, and OCT4, which function in maintaining stem cell survival, self-renewal, and pluripotency. For example, SOX2 is transcriptionally repressed by $\mathrm{AR}$, and, as expected, treating multiple PCa cell lines with the antiandrogen enzalutamide has been shown to increase SOX2

Published by Bioscientifica Ltd. 
expression and to lead to CRPC tumor formation (Kregel et al. 2013). AR has also been reported to directly bind to the NANOG promoter (Kregel et al. 2014) to impart castration resistance in $\mathrm{LNCaP}$ cells driven by the expansion of $\mathrm{CD} 133^{+}$and $A L D H 1^{+}$CSCs (Jeter et al. 2011). Apart from direct transcriptional regulation, AR can also indirectly modulate the Wnt (Bisson \& Prowse 2009), PI3K/AKT (Dubrovska et al. 2009), and hedgehog (Gowda et al. 2013) signaling cascades, which play an important role in regulating PCa CSC self-renewal. Together, these findings beg the question of how $\mathrm{AR}$ is reprogrammed to facilitate CSC plasticity and CRPC progression. A pioneering study by Xu et al. (2012) demonstrated that in CRPC, $\mathrm{AR}$ is recruited to distinct genomic sites, where it executes a distinct transcriptional program to drive tumor cell proliferation and survival. This shift in the AR binding landscape requires the co-factor EZH2, an epigenetic regulator with a well-documented role in regulating cell identity (Margueron \& Reinberg 2011). Although the resultant chromatin architectural and mechanistic consequences are not fully understood, CSC plasticity is probably mediated at least in part by the cooperation of AR and EZH2.

The impressive recent crescendo of experimental observations that implicate cytokines and growth factors in enhancing the CSC phenotype underscore the role of the tumor microenvironment in the phenotypic plasticity of tumor cells and CSCs. We recently learned from a study by Wang et al. (2013) that endothelial cells within the prostate are increased following ADT. These cells secrete interleukin 6 (IL6), which activates PI3K/AKT signal transduction to suppress AR transactivation (Yang et al. 2003). Intriguingly, elevated PI3K/AKT activity coincides with stem cell activation and maintenance (Segrelles et al. 2014), and treating mice with soluble IL6 receptor fusion protein or silencing PI3K in tumor cells has been shown to significantly suppress prostate tumor growth via a reduction in the CSC population (Dubrovska et al. 2009, Schroeder et al. 2014). IL6 has also been reported to activate NF- $\mathrm{BB}$ to maintain and expand the CSC population in breast cancer (Korkaya et al. 2012) and PCa (Rajasekhar et al. 2011). Notably, the overexpression of NF$\kappa \mathrm{B}$ in LNCaP cells has been shown to confer resistance to enzalutamide (Nadiminty et al. 2013), possibly through the expansion of the CSC population. Hence, targeting the androgen axis modulates CSC plasticity not only through direct transcriptional regulation, such as SOX2 and $N A N O G$, but also by affecting multiple cell types that comprise the tumor microenvironment.

\section{Prostate tumor plasticity: epithelial-mesenchymal transition}

In addition to expanding CSCs, androgen deprivation is also known to direct the plasticity of transformed epithelial prostate cells toward a mesenchymal cell state, or vice versa. Epithelial-mesenchymal transition (EMT) is a developmental process wherein epithelial cells begin expressing mesenchymal markers in response to tumor microenvironmental stimuli; they also lose cell adhesions, change shape, and become more migratory and invasive. Ultimately, this process allows tumor cell dissemination and the formation of distant metastases (Kalluri \& Weinberg 2009, Lim \& Thiery 2012, Sun et al. 2012). In normal development and in $\mathrm{PCa}$, this transition is controlled by the expression of the epithelial marker E-cadherin, which when down-regulated allows factors that drive EMT, such as ZEB1, TWIST, SLUG and SNAIL, $\beta$-catenin, and ETS1, to drive the expression of mesenchymal markers, including $N$-cadherin, vimentin, fibronectin, cadherin 11, collagen 1, $\alpha 2(b) \beta 3$ integrin, and syndecan 1 (Anose et al. 2008, Jennbacken et al. 2010, Shiota et al. 2010, Zhu \& Kyprianou 2010, Matuszak \& Kyprianou 2011, Yates 2011, Clyne 2012, Wu et al. 2012). Recently, the use of the term 'phenotypic plasticity' has also included reversible mesenchymal-epithelial transition (MET) that occurs in cancer cells when mesenchymal cells revert to an epithelial-like phenotype once they have established metastases in new organs (Nieto 2013). Moreover, there is close association between the CSCs and EMT in PCa, although the relationship between these two dynamic states is unclear. However, what is known is that this tumor cell epithelial plasticity is implicated in PCa metastasis and therapeutic resistance, and, like CSCs, it is controlled by the AR.

\section{AR as a regulator of EMT}

Multiple studies have shown that mesenchymal markers, including $N$-cadherin, vimentin, ZEB1, TWIST, and SNAI2, are highly expressed in androgen-deprived patient tumors, cell lines, and xenografts and mouse models, and a number of AR-dependent mechanisms of EMT control have been proposed (Liu et al. 2008, Zhu et al. 2010, Sun et al. 2012, Izumi et al. 2013, Lin et al. 2013a,b). In patientderived tissue slice grafts, 6-10 weeks of flutamide or lupron treatment was shown to induce the expression of the mesenchymal marker vimentin and to cause the mislocalization of E-cadherin (Zhao et al. 2013). Similarly, androgen deprivation caused EMT, as was shown by the

Published by Bioscientifica Ltd 
overexpression of N-cadherin, ZEB1, TWIST1, and SLUG in normal mouse prostate tissue, in LuCaP35 xenografts, and in PCa patients tissue xenografts as well as in LNCaP cells cultured in charcoal-stripped serum (Sun et al. 2012). In addition, the mesenchymal marker cadherin 11, which is overexpressed especially in bone metastasis of $\mathrm{PCa}$, is reduced by androgens in PCa cell lines, which may be regulated by the AR at the transcriptional level (Lee et al. 2010). Indeed, multiple studies have shown an association between the AR and EMT transcription factors. Under ADT conditions, EMT has been shown to be mediated via a feedback loop of AR and the EMT transcription factor $Z E B 1$, as was evidenced by the mutual exclusive expression of $\mathrm{AR}$ and $Z E B 1$ in castration-sensitive (LNCaP) and castration-resistant (CWR22Rv1, PC-3, and DU145) PCa cell lines. This was further supported by the up-regulation of ZEB1 in AR-silenced, TSA, and 5-Aza treated cells and the up-regulation of AR in shZeb1 cells treated with TSA and 5-Aza (Sun et al. 2012). ZEB2 has also been recently identified as being overexpressed in PCa as compared to benign prostatic hyperplasia and was described as being AR-regulated; AR positively regulates $Z E B 2$ in androgen-dependent cells, but it is a negative regulator of ZEB2 in androgen-independent PCa cells (Jacob et al. 2014). The authors of this last study demonstrated that $Z E B 2$ expression is up-regulated in response to androgen stimulation and down-regulated after the silencing of AR in androgen-dependent LNCaP cells. However, androgen-independent PC-3 and DU145 cells expressed higher levels of $Z E B 2$ than $\mathrm{LNCaP}$ cells did, and forced AR expression in these cells reduced ZEB2 expression, invasiveness, and migration and increased the levels of the ZEB2 transcriptional target E-cadherin (Jacob et al. 2014). These results support the idea that AR-regulated EMT is a cell context-dependent phenomenon in PCa. Importantly, however, the detailed mechanism that describes how $\mathrm{AR}$ and $Z E B 1 / 2$ interact to inhibit each other has not been described.

In addition to $Z E B 1 / 2$, the Snail family zinc-finger transcription factor $S L U G$ was recently identified as being androgen-regulated and as being a coordinator of $\mathrm{AR}$ that promotes the development of CRPC (Wu et al. 2012). Wu et al. found that the presence of constitutively active AR induced SLUG expression. That study also showed that SLUG formed a complex with AR and acted as a co-activator by enhancing AR transcriptional activity even in the absence of androgen and thus providing a growth advantage in androgen-deprived conditions in CRPC (Wu et al. 2012). Furthermore, the authors indicated that PCa cells that overexpress the AR splice variants ARV7, AR3, and Arv567es show induced SLUG expression. Constitutively active AR splice variants are important regulators of aberrant androgen signaling, because these variants are able to maintain androgen signaling in the absence of androgens as a result of the lack of ligand binding domain. Thus, this study suggests that cooperation between SLUG and AR variants might drive an aggressive EMT phenotype in CRPC (Wu et al. 2012).

Many other pathways that converge with the AR regulate EMT in CRPC, including the growth factor receptor tyrosine kinase (RTK), PTEN, notch, hedgehog, Wnt, and TMPRSS2:ERG pathways (Leshem et al. 2011, Kim et al. 2014) and the STAT3 pathway (Karhadkar et al. 2004, Acevedo et al. 2007, Bisson \& Prowse 2009, Mulholland et al. 2012). For example, in a study by Izumi et al., the silencing of AR in LNCaP cells and PCa mouse xenograft models was shown to promote cell migration by up-regulating the CCL2-dependent STAT3 and EMT pathways. The authors suggest that co-targeting CCL2/CCR2-STAT3 signaling may provide a novel therapeutic approach for targeting $\mathrm{PCa}$ progression and metastasis at the castration-resistant stage (Izumi et al. 2013). In another study, ADT induced cell invasion that was reversed by targeting pSTAT3-CCL2 signaling in PCa cells and in mouse models (Lin et al. 2013a). In addition to CCL2, STAT3 signaling and EMT have also been shown to be regulated by HSP27, which is increased after ADT in CRPC (Rocchi et al. 2005, Shiota et al. 2013, Cordonnier et al. 2015). Silencing HSP27 reversed an EMT phenotype by reducing STAT3 phosphorylation and subsequent binding to the TWIST promoter and also by reducing EGF-mediated EMT via the modulation of the $\beta$-catenin/SLUG signaling pathway (Shiota et al. 2013, Cordonnier et al. 2015). Because $\beta$-catenin is also up-regulated in CPRC, co-localizes with $\mathrm{AR}$ in the nucleus, and can act as an AR co-activator, targeting $\beta$-catenin-AR interactions may represent a potential novel therapeutic strategy for preventing transcriptional activation of AR in CRPC and AR-dependent EMT (Robinson et al. 2008, Schweizer et al. 2008, Wang et al. 2008). Moreover, these results suggest that targeting HSP27 and/or STAT3 may reverse EMT in advanced PCa. Taken together, several EMT-associated pathways and EMT markers have been shown to be regulated by ADT, and aberrant AR signaling in particular has been proposed to induce EMT and to regulate epithelial cell plasticity in CRPC. However, we have yet to define the detailed molecular mechanisms that underlie how AR regulates cell plasticity and to identify potential common drivers for these phenotypes.

Published by Bioscientifica Ltd 


\section{Tumor cell plasticity: alternative epithelial-myeloid transition}

The many observations of the emergence of CSCs and cells that have undergone EMT in therapy-resistant PCa highlight the importance of AR-regulated tumor cell plasticity as a driver of advanced disease. However, the diversity of tumor cell types that may arise from CSCs or are included in this 'plasticity' are now broader than was originally thought. For example, an alternative epithelial-myeloid version of EMT (EMyT) has been proposed for tumor cells. The EMyT theory is based on the overlap in the expression of cluster of differentiation (CD) markers, pattern recognition receptors (PRRs), cytokine and growth factor receptors, and matrix metalloproteases in cancer cells that typically define multiple myeloid cell lineages of the immune system (Schramm 2014). Although the therapeutic implications of this alternative immune EMyT for most tumor types has yet to be established, there is mounting evidence in PCa that certain myeloid marker expression correlates with aggressive tumor cell behavior. Moreover, because CSCs and EMT phenotypes are dictated by AR activity in $\mathrm{PCa}$, this myeloid plasticity may likewise be androgen-regulated.

\section{AR regulation of epithelial-myeloid transition}

Depending on the AR expression in PCa cell lines, there is differential expression of toll-like receptors (TLRs), which are innate PRRs that normally function to alert immune cells and epithelial cells to infection by bacteria, viruses, or parasites. Although the mechanisms of immune evasion by cancer cells that express TLRs are outside the scope of this review, the presence of TLRs in PCa does have clinical relevance. The increased expression of TLR3 and TLR9 in patients with primary $\mathrm{PCa}$ has been shown to predict biochemical recurrence of CRPC (Gonzalez-Reyes et al. 2011), and in African American men, polymorphisms in TLR2 were shown to be a significant predictor of PCa risk (Rogers et al. 2013). Interestingly, whereas androgendependent LNCaP cells stimulated with the TLR3 agonist poly:IC (double-stranded RNA) undergo apoptosis, AR-negative PC3 cells activate an interferon response pathway that leads to the up-regulation of inflammatory mediators, which may promote tumor progression (Palchetti et al. 2015). LNCaP cells and PC3 cells also respond differently to stimulation with the TLR2 agonist lipoteichoic acid (LTA), which increases the invasiveness of LNCaP cells but decreases that of PC3 cells (Rezania et al. 2014). Although these studies have not directly addressed the androgen regulation of TLR expression or function, they suggest that the association of TLR expression with an increased risk of PCa development or recurrence could reflect differences in degrees of AR activity, and they speak to the effects that mainstay anti-androgen treatments could have on driving the emergence of an EMyT phenotype in PCa tumors.

In addition to TLRs, we have also recently reported the up-regulated expression of the T cell checkpoint molecule programmed death ligand 1 (PDL1) on enzalutamideresistant CRPC cells (Bishop et al. 2015). The interaction between PDL1 or PDL2 and their receptor, PD1, which is located on T cells, inhibits antitumor immune responses and makes this pathway a key target of checkpoint blockade immunotherapies, especially in cancer types that up-regulate $P D L 1$ on the surface for immune evasion (Sharma \& Allison 2015). Whereas PDL1 on CRPC patient tumors has been difficult to detect or non-existent (Brahmer et al. 2010, Topalian et al. 2012, Taube et al. 2014), the expression of other inhibitory molecules in the B7 family, such as B7H3, correlate with poor prognosis in PCa (Zang et al. 2007). Furthermore, we have shown that the up-regulation of many $\mathrm{B} 7$ family members, including PDL1, may be unique and specific to anti-androgenresistant CRPC (Bishop et al. 2015). In addition, PDL1 was not the only immune marker expressed by these enzalutamide-resistant cells. Transcriptome profiling of these unique cell lines has indicated that they harbor a genetic signature that is associated with the differentiation and maintenance of myeloid cells from the hematopoietic compartment. For example, enzalutamide-resistant cells showed a marked up-regulation of genes that encode for the antigen presentation HLA complexes, which are cell surface markers and cytokines that are characteristic of myeloid cells, such as FLT3/L, BDCA3, CD11B, IL12, and IL15, as compared to CRPC controls (Fig. 1A). Moreover, these cells were characterized as overexpressing genes that encode transcription factors associated with the development of dendritic cells (DCs) and/or monocytes from common myeloid precursors, including interferon response elements (IRFs), inhibitor of differentiation factors (ID1-ID3), Ikaros (IKZF1), BATF3, and RELB (Fig. 1B). Importantly, the PDL1 expression and myeloid markers presented in that study were only up-regulated in enzalutamide-resistant CRPC cells that showed inactivation of the classical AR pathway (Bishop et al. 2015), which suggests that as with TLR expression, the androgen axis may control checkpoint molecule expression in PCa.

The full extent of how myeloplastic cells affect PCa progression has yet to be defined; however, mounting

Published by Bioscientifica Ltd. 
A

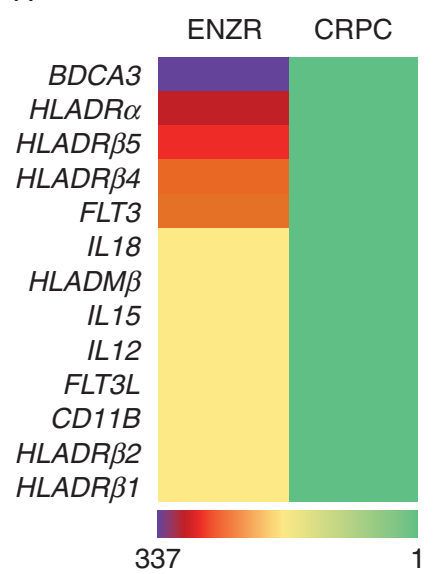

B

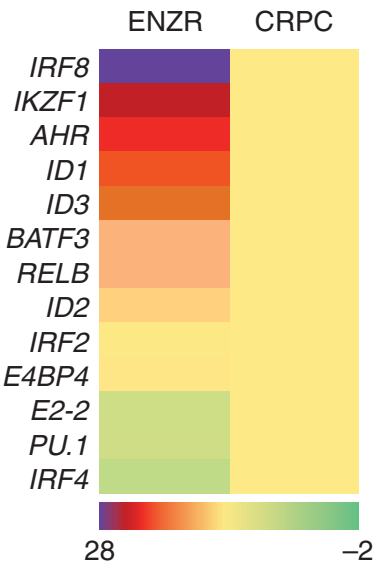

\section{Figure 1}

Myeloid differentiation signature in enzalutamide-resistant (ENZR) CRPC Total RNA was isolated from ENZR or CRPC cells shown to have low AR activity (Bishop et al. 2015), and transcriptomic profiling using microarray was performed. Heat maps show that fold change in the gene expression of myeloid cell surface marker or cytokines (A) and the transcription factors required for myeloid cell differentiation (B) are up-regulated in ENZR cells as compared to $\operatorname{CRPC}(=1)$.

evidence suggests that the expression of myeloid markers alters the way tumors respond to and manipulate their microenvironments. For example, beyond inhibiting $\mathrm{T}$ cell responses, tumor-intrinsic PDL1, which is up-regulated after chemotherapy or targeted therapy, can 'reverse signal' to prevent apoptosis (Azuma et al. 2008), thereby enhancing tumor survival. Reciprocally, MYD88 expression in the spontaneous PCa TRAMP tumor model dictates the immune infiltrate into tumors by recruiting myeloid-derived suppressor cells and inhibiting NK cell populations, which promotes PIN and tumor progression (Peek et al. 2015). Manipulation of NK cell function has also been demonstrated in other studies, which indicate that the expression of the NK cell activating ligand NKG2D by PCa tumor-derived exosomes selectively downregulates $N K G 2 D$ expression on circulating $\mathrm{NK}$ and cytotoxic T cells; this prevents their antitumor activity in vitro (Lundholm et al. 2014). Our previous results also suggested a correlation between tumor-intrinsic myeloid marker expression and manipulation of the immune compartment, seeing as we found that only enzalutamide-resistant CRPC tumor cells that express PDL1 were able to prevent DC infiltration into tumors and increase the frequency of circulating DC expression of PDL1 and PDL2 in vivo (Bishop et al. 2015). Again, this cross-talk between tumor and immune cell checkpoint expression may be dictated to some degree by AR activity, seeing as only enzalutamide-resistant tumors with low AR activity had these effects on circulating or tumor-infiltrating DCs (Bishop et al. 2015). We also found that patients who progressed on enzalutamide had significantly increased PDL $1 / 2^{+}$DCs in their blood as compared to those who were naïve or responded to treatment, and in progressing patients, more $P D L 1 / 2^{+}$DCs were associated with a poorer initial response to enzalutamide and longer treatment duration (Bishop et al. 2015). Together, these studies suggest that further experiments in both patients and in vivo PCa tumor models should be conducted to evaluate how EMyT contributes to disease progression in the androgen-dependent, CRPC, and anti-androgen phases of PCa.

\section{Tumor cell plasticity: neuroendocrine transdifferentiation}

The correlation between altered AR expression and/or activity and a change in PCa tumor cell phenotype is best exemplified by the progression of PCa adenocarcinoma to neuroendocrine PCa (NEPC). Although the healthy prostate contains neuroendocrine cells, there is little scientific evidence to support the idea that these cells undergo transformation to give rise to NEPC (Terry \& Beltran 2014). Instead, multiple studies have suggested that under the selective pressure of potent AR inhibition in late-stage CRPC, PCa adenocarcinoma 'transdifferentiates' to NEPC (Lin et al. 2014), which does not at all rely on AR for survival or proliferation. This transdifferentiation process is defined by a number of pathological and clinical features (Epstein et al. 2014) as well as molecular alterations that indicate the adenocarcinoma origin of NEPC, such as TMPRESS2-ERG rearrangements (Lapuk et al. 2012, Logothetis et al. 2013), the loss of AR and/or AR-regulated target genes, the loss of RB1, the amplification of NMYC and AURKA, and the induction of neural differentiation programs (Beltran et al. 2011, Logothetis et al. 2013, Park et al. 2014). Full reviews on NEPC can be found elsewhere (Tagawa 2014, Terry \& Beltran 2014, Vlachostergios \& Papandreou 2015); however, in the following sections, we outline key studies that show the relationship between the NEPC transdifferentiation process and AR.

\section{AR regulation of NEPC}

The rise in incidences of non-AR-driven CRPC, which may include up to $25 \%$ of patients with late-stage PCa and does include men with NEPC (Aparicio et al. 2011), underscores how AR activity dictates tumor cell plasticity at every stage

Published by Bioscientifica Ltd 
of PCa progression. Indeed, multiple potential 'drivers' of NEPC have been identified, almost all of which precede, accompany, or are controlled by a loss of AR expression or activity. For example, although the AR is a major regulator of PCa cell proliferation, in NEPC models without AR expression, mitotic deregulation that leads to hyperproliferation occurs upon the loss of RB1 and cyclin D1, which suggests that the loss of this key tumor suppressor pathway may actually precede the AR loss that is observed in NEPC (Tzelepi et al. 2012). Indeed, up to $90 \%$ of NEPC tumors lack RB1 (Tan et al. 2014), which highlights the importance of cell cycle regulators in this disease. In addition, the mitotic phase kinase AURKA controls NEPC, which in turn is regulated by NMYC (Beltran et al. 2011) as well as REST (Svensson et al. 2014), both of which are inversely correlated with AR in PCa (Lapuk et al. 2012). Moreover, pathways that are known to also feedback on the AR, such as IL6 and cAMP signaling, can drive an NE phenotype in LnCaP cells (Cox et al. 2000, Spiotto \& Chung 2000). Indeed, prolonged exposure to IL6 can reduce AR expression (Debes et al. 2005), which further suggests that there is an important link between this cytokine and an AR-negative NEPC phenotype. In addition, a number of genes are up-regulated after ADT, and they are thus presumed to be androgen-suppressed and are associated with a progression to NEPC or non-AR-driven 'anaplastic' CRPC, including ARG2 (Kani et al. 2013), hASH-1 (Rapa et al. 2013) and protocadherins (Terry et al. 2013). Importantly however, although many studies have shown an inverse correlation between NEPC and AR expression or activity, no reports have indicated a direct mechanism by which a loss of AR actually drives this phenotype.

\section{Tumor cell plasticity: overlap in aggressive cell phenotypes}

Because the AR clearly plays a role in directing the CSC, EMT, EMyT, and NEPC phenotype and/or functions of PCa cells, it is not surprising that ADT induces the up-regulation of CSC, NEPC, and EMT markers simultaneously. Indeed, many reports in PCa as well as other cancers have shown a correlation between the expression of EMT and CSC markers within the same cells. For example, after androgen deprivation, both EMT and CSC populations have been shown to increase in mouse prostates and PCa cells (Scheel \& Weinberg 2012). Likewise, PCa cells that were induced to an EMT phenotype, or CSCs that were isolated from PCa cell lines, have been shown to strongly up-regulate transcription factors expressed by CSCs and markers of EMT respectively, and they have been found to be highly tumorigenic in mice (Kong et al. 2010, Salvatori et al. 2012). In the aforementioned studies wherein ADT induced EMT, the authors also observed increases in CSC as well as NEPC characteristics (Sun et al. 2012). Reciprocally, LNCaP C-33 cells, which have an NE phenotype, express higher levels of the EMT transcription factor SNAIL, and the overexpression of SNAIL in LNCaP cells increases terminal markers of NE differentiation (McKeithen et al. 2010). Other studies have shown that AR splice variants simultaneously induce EMT and stem cell markers in PCa. In ADT culture conditions (CSS), AR and AR3 (ARV7) as well as the EMT/CSC markers LIN28B, NANOG, and SOX2 and EMT markers, such as ZEB1, TWIST, N-cadherin, and vimentin, are overexpressed (Kong et al. 2015). The authors also indicated that AR3 expression was positively correlated with LIN28 in PCa patient tumors and suggested that the AR3 inhibitor BR-DIM acts as a novel agent to inhibit AR, AR variants, and cancer stem cell markers in PCa (Kong et al. 2015). The overlap of CSC and EMT markers also occurs in mouse models of PCa: $\mathrm{ADT}$ has been shown to promote EMT and the expression of the CSC marker Cd44 in castrated TRAMP mouse tumors. Seeing as a defining feature of stem cells is their pluripotent potential to give rise to other cell types, it is not surprising that the authors suggested that a switch from $C D 44^{+}$cells to EMT cells is the driver of metastasis in PCa; they showed that this switch occurs through a TGFB1-CD44 signaling pathway (Shang et al. 2015). Future studies should further this work to determine whether CSCs are truly precursors or are required for the induction of EMT, EMyT, or NEPC phenotypes in PCa cells, especially under ADT conditions.

Like the close association between cells that undergo traditional EMT and CSCs, myeloplastic cancer cells may also share CSC and/or mesenchymal phenotypes. Although this concept has been less explored in PCa, examples have been found in other solid tumor types that may be relevant to PCa studies. For example, basal breast cancers, which are highly enriched for CSCs (Foulkes et al. 2010), have the highest expression of PDL1 as compared to other breast cancer subtypes (Soliman et al. 2014), and $20 \%$ of triple negative breast cancer (TNBC) cases, of which about $80 \%$ are basal, express PDL1 (Mittendorf et al. 2014). This suggests that enzalutamide-resistant tumor cells, in which PDL1 is expressed, may have either CSC or EMT traits, and this would be in accordance with their low AR activity. Beyond the overlap between CSC and immune markers, EMyT in tumor cells may actually support mesenchymal or stem cell properties. For example,

Published by Bioscientifica Ltd. 
NKG2D expression in breast cancer has been shown to drive EMT and to support CSC maintenance via the transcription factor SOX9 (Cai et al. 2014). Because NKG2D exists on PCa exosomes, an intriguing hypothesis may be that in addition to driving immune suppression, exosomal NKG2D supports tumor cell EMT and CSCs via a paracrine mechanism. Functionally, this strong overlap between CSC and myeloplastic phenotypes might dictate tumor progression by affecting how these tumors interact with the immune response. Murine metastatic lung cancer that was selectively passaged in vivo because of its ability to evade immune responses in vaccinated mice expressed high levels of CSC markers (Noh et al. 2012), and the pluripotency transcription factor $N A N O G$ is required to protect tumor cells from cytotoxic $\mathrm{T}$ cell death both in vitro and in vivo (Mao et al. 2014). Intriguingly, in one study, up to $50 \%$ of small-cell lung cancer patients mounted antigen-specific $\mathrm{T}$ cell responses to another stem cell transcription factor, $S O X 2$, and these responses were associated with tumor regression after immunotherapy against PD1 (Dhodapkar et al. 2013). In PCa, SOX2 has also been identified as a tumor-associated antigen (TAA) (Shih et al. 2014). These studies seem to bring full circle the association between strong PDL1 expression by solid tumor types and CSC properties, and they suggest that immune correlates of response to or progression with therapies may also benefit from investigating the CSC phenotype of tumors.

\section{Targeting androgen response-driven cellular plasticity to improve patient outcomes}

Suppressing AR signaling remains the focus of therapeutic strategies for advanced PCa, which is justified given the success of second-generation anti-androgens such as enzalutamide. Despite these advancements, many patients are impervious to further targeting of AR signaling, and none have been cured. This probably reflects the heterogeneity and plasticity of lethal prostate tumors, which are comprised of a mixed population of cells with varying degrees of AR expression. Notably, prostate CSCs probably have reduced AR signaling (Qin et al. 2012) and are believed to be intricately linked to EMT, EMyT, and metastasis (Mani et al. 2008). These observations support the process of co-targeting cellular plasticity as a rational therapeutic strategy for suppressing metastasis and CRPC. A list of potential agents is provided in Table 1 .

Given the significant overlap between the plastic phenotypes of PCa tumor cells and the potential for CSCs to be the source of these phenotypes, targeting key molecules and signaling pathways that sustain prostate CSCs could lead to the development of new therapies that improve clinical disease management. One exciting preclinical study found that the inhibition of the hedgehog signaling pathway using the smoothened inhibitors cyclopamine and GDC-0449 depleted the CSC population and reduced CRPC xenograft growth (Domingo-Domenech et al. 2012). More recent work uncovered the therapeutic potential of inhibiting $M Y C$, a transcription factor with a central function in the maintenance of CSCs and NEPC. Using a novel in vivo delivery system, Civenni et al. (2013) demonstrated that the systemic delivery of Myc-targeted siRNA to mice bearing PC-3 CRPC xenografts reduced the CSC population and suppressed tumor growth and metastasis. Although MYC inhibitor design has been difficult because of the absence of a clear ligand binding domain, BET inhibitors have been shown to reduce MYC expression in PCa models (Wyce et al. 2013) and have demonstrated astounding therapeutic efficacy in blocking CRPC tumor growth (Asangani et al. 2014). Alternatively, targeting $E Z H 2$ has gained traction within the sphere of CSC-directed therapy. In LNCaP and PC-3 cells, EZH2 was found to be up-regulated specifically within the $C D 44^{+} / C D 133^{+}$CSC population (Sun et al. 2013), and DZNep, which induces the degradation of $E Z H 2$, eradicated the CSCs and attenuated DU145 CRPC tumor growth (Crea et al. 2011). GlaxoSmithKline is currently testing a highly specific EZH2 inhibitor, GSK2816126, in a phase I clinical trial for relapsed/refractory lymphoma. Interestingly, their preclinical studies showed that glioblastoma stem cells responded well to this inhibitor (Kim et al. 2013), which suggests that it could be repositioned to eradicate prostate CSCs. Finally, STAT3 inhibitors have also been shown to reduce CSC populations; galiellalactone was able to reduce $A L D H$-positive PCa cells (Baritaki et al. 2009, Hellsten et al. 2011), and another STAT3 inhibitor, LLL12, has been shown to reduce the CSC phenotype in patient-derived castrate-resistant tumors (Kroon et al. 2013).

In addition to these small-molecule inhibitors of CSCs, a major avenue of exploration in other cancers that could translate to CRPC treatments is the use of immunotherapies to target CSC populations. For example, in glioblastoma, $C D 133$ has been shown to be a TAA (Ji et al. 2014), as has SOX2 in small-cell (Gure et al. 2000, Vural et al. 2005, Shih et al. 2014) and non-small-cell (Dhodapkar et al. 2013) lung cancer. Antigen-specific $\mathrm{T}$ cells in both cases were able to induce CSC killing, which makes them strong potential vaccine candidates. In head and neck, breast, and pancreatic cancer, the transfer

Published by Bioscientifica Ltd 
Table 1 Opportunities for therapeutic targeting of cellular plasticity

\begin{tabular}{|c|c|c|c|}
\hline Plasticity factor & Drug & Mode of action & Clinical trials \\
\hline \multirow[t]{3}{*}{ Hedgehog } & Cyclopamine & $\begin{array}{l}\text { Directly binds to and inhibits the } \\
\text { smoothened receptor to } \\
\text { antagonize hedgehog signaling }\end{array}$ & Preclinical \\
\hline & GDC-0449 & & $\begin{array}{l}\text { Phase } \mathrm{I} / \mathrm{II} \text { combination study with hormone } \\
\text { therapy in locally advanced PCa } \\
\text { (NCT01163084) }\end{array}$ \\
\hline & & & $\begin{array}{l}\text { Phase I pharmacokinetic study in mCRPC } \\
\text { (NCT02115828) }\end{array}$ \\
\hline \multirow[t]{3}{*}{$M Y C$} & JQ1 & $\begin{array}{l}\text { Targets BET bromodomain proteins } \\
\text { that are required for the tran- } \\
\text { scriptional activation of } M Y C\end{array}$ & Preclinical \\
\hline & $\begin{array}{l}\text { I-BET762 } \\
\quad \text { (GSK525762) }\end{array}$ & & $\begin{array}{l}\text { Phase I dose escalation study in acute leukemia } \\
\text { (NCT01943851) }\end{array}$ \\
\hline & TEN-010 & & $\begin{array}{l}\text { Phase I dose escalation study in advanced solid } \\
\text { tumors (NCT01987362) }\end{array}$ \\
\hline \multirow[t]{4}{*}{$E Z H 2$} & DZNep & Degrades PRC2 complex & Preclinical \\
\hline & El1 & $\begin{array}{l}\text { Inhibits histone methyltransferase } \\
\text { activity }\end{array}$ & Preclinical \\
\hline & EPZ-6438 (E7438) & & $\begin{array}{l}\text { Phase } 1 / I \text { combination study with standard } \\
\text { chemotherapy in advanced solid tumors and } \\
\text { B cell lymphoma (NCT01897571) }\end{array}$ \\
\hline & $\begin{array}{l}\text { GSK2816126 (GSK126 } \\
\text { analogue) }\end{array}$ & & $\begin{array}{l}\text { Phase I dose escalation study in relapsed/ } \\
\text { refractory lymphoma malignancies } \\
\text { (NCT02082977) }\end{array}$ \\
\hline PKC/TWIST & Ro31-8220 & Inhibits PKC & Preclinical \\
\hline$N$-cadherin & $\mathrm{ADH}-1$ & Inhibits $N$-cadherin & $\begin{array}{l}\text { Phase I study of Exherin (ADH-1) in advanced } \\
\text { solid tumors. (NCT00265057) }\end{array}$ \\
\hline STAT3 & $\begin{array}{l}\text { Galiellalactone or } \\
\text { LLL12 }\end{array}$ & $\begin{array}{l}\text { Inhibits STAT3 transcriptional } \\
\text { activity }\end{array}$ & Preclinical \\
\hline \multirow[t]{2}{*}{ HSP27 } & OGX-427 & Inhibits HSP27 & $\begin{array}{l}\text { Phase II study of OGX-427 in CRPC } \\
\text { (NCT01120470) }\end{array}$ \\
\hline & Silibinin & Induces MET & Preclinical \\
\hline NF- $\kappa B / S N A I L / R K I P$ & NPI-0052 & Inhibits the proteasome & $\begin{array}{l}\text { Phase I study in advanced solid tumor } \\
\text { malignancies or refractory lymphoma } \\
\text { (NCT00396864) }\end{array}$ \\
\hline $\begin{array}{l}\text { Androgen receptor } \\
\text { variant AR3 }\end{array}$ & BR-DIM & $\begin{array}{l}\text { Reduces the expression of AR3 and } \\
\text { EMT markers }\end{array}$ & $\begin{array}{l}\text { Phase I dose-escalation study of oral } \\
\text { BioResponse 3,3'-Diindolylmethane } \\
\text { (BR-DIM) in nmCRPC }\end{array}$ \\
\hline ARV7 & EPI-001 & $\begin{array}{l}\text { Blocks AR NTD transcriptional } \\
\text { activity }\end{array}$ & Preclinical \\
\hline \multirow[t]{2}{*}{ Cadherin-11 } & mAbs $2 \mathrm{C} 7$ and $1 \mathrm{~A} 5$ & $\begin{array}{l}\text { Monoclonal antibody that targets } \\
\text { cadherin-11 }\end{array}$ & Preclinical \\
\hline & $\begin{array}{l}\text { RSC (yeast)-Twist } \\
\text { vaccine }\end{array}$ & Induces TWIST-specific cytoxic T cells & Preclinical \\
\hline Brachyury & $\begin{array}{l}\text { MVA-brachyury- } \\
\text { TRICOM vaccine }\end{array}$ & $\begin{array}{l}\text { Induces Brachyury-specific cytotoxic } \\
\text { T cells }\end{array}$ & $\begin{array}{l}\text { Phase I study in advanced tumors (prostate } \\
\text { included) (NCT02179515) }\end{array}$ \\
\hline PD1 & CT-001 & $\begin{array}{l}\text { Monoclonal antibody that blocks } \\
\text { PD1 ligation }\end{array}$ & $\begin{array}{l}\text { Phase II study of CT-001, Provenge, and } \\
\text { cyclophosphamide in CRPC (NCT01420965) }\end{array}$ \\
\hline$P D L 1$ & MSB0010718C & $\begin{array}{l}\text { Monoclonal antibody that blocks } \\
\text { PDL1 ligation }\end{array}$ & Phase I study in CRPC (NCT01772004) \\
\hline AURKA & MLN8237 & Inhibits AURKA & $\begin{array}{l}\text { Phase II study in mCRPC and NEPC } \\
\text { (NCT01799278) } \\
\text { Phase I study of Docetaxel in CRPC } \\
\text { (NCT01094288) }\end{array}$ \\
\hline
\end{tabular}

of autologous CD8T cells specific for recognizing the stem cell enzyme $A L D H A 1 A$ have also been shown to have antitumor efficacy. Seeing as SOX2 has also been identified as a TAA in PCa (Shih et al. 2014), and seeing as PCa CSCs

\begin{tabular}{|lr}
\hline http://erc.endocrinology-journals.org & (C) 2015 Society for Endocrinology \\
DOI: $10.1530 /$ ERC-15-0137 & Printed in Great Britain
\end{tabular}

express both $C D 44$ and $A L D H A 1 A$, it may be that such immunotherapies could work against PCa CSCs as well.

A major caveat of these therapeutic targets is that they are not 'pure' CSC factors; rather, they are shared with

Published by Bioscientifica Ltd. 
normal stem cells. Therefore, a more optimal strategy might be to exploit the fact that prostate CSCs express unique cell surface markers, such as $C D 44$ and $C D 133$, by targeting drugs specifically to these cells. CD44-targeted nanoparticles carrying MDR1 siRNA have demonstrated efficacy in sensitizing ovarian cancer cells, as well as the CSCs, to paclitaxel in vivo (Yang et al. 2015). Nanoparticles are also capable of delivering anticancer therapeutics to CSCs; for example, CD133-coated nanoparticles carrying paclitaxel significantly reduced the CSC burden and lowered the rate of tumor relapse in a breast cancer xenograft model (Swaminathan et al. 2013). Although this technology is still in its infancy, it shows great promise for tumor cell-specific targeting.

Another approach to mitigating the adverse side effects of CSC targeting is to inhibit other aspects of CRPC tumor cell plasticity, such as EMT, NEPC, or immune evasion, more directly. Targeting EMT markers such as $\beta$-catenin, fibronectin, cadherin- 11 , or vimentin has been proposed as a potential strategy for reducing CRPC cell viability. For example, the therapeutic targeting of $N$-cadherin with a MAB has been shown to successfully delay PCa progression by reducing PC-3 and castrateresistant LAPC4 tumor xenograft growth and invasion (Tanaka et al. 2010). In addition, targeting the mesenchymal marker cadherin-11 with an antibody was recently reported to reduce bone metastases in a PC3-mm2 xenograft model (Lee et al. 2013b). In addition, proteins and signaling pathways that control EMT have also been suggested to be potential drug targets in PCa cells that have EMT phenotype. For example, the proteasome inhibitor NPI-0052 is able to inhibit the NF-кB/SNAIL/ RKIP pathway in metastatic PCa (Baritaki et al. 2009). In addition, the Hsp27 inhibitor OGX-427, which is

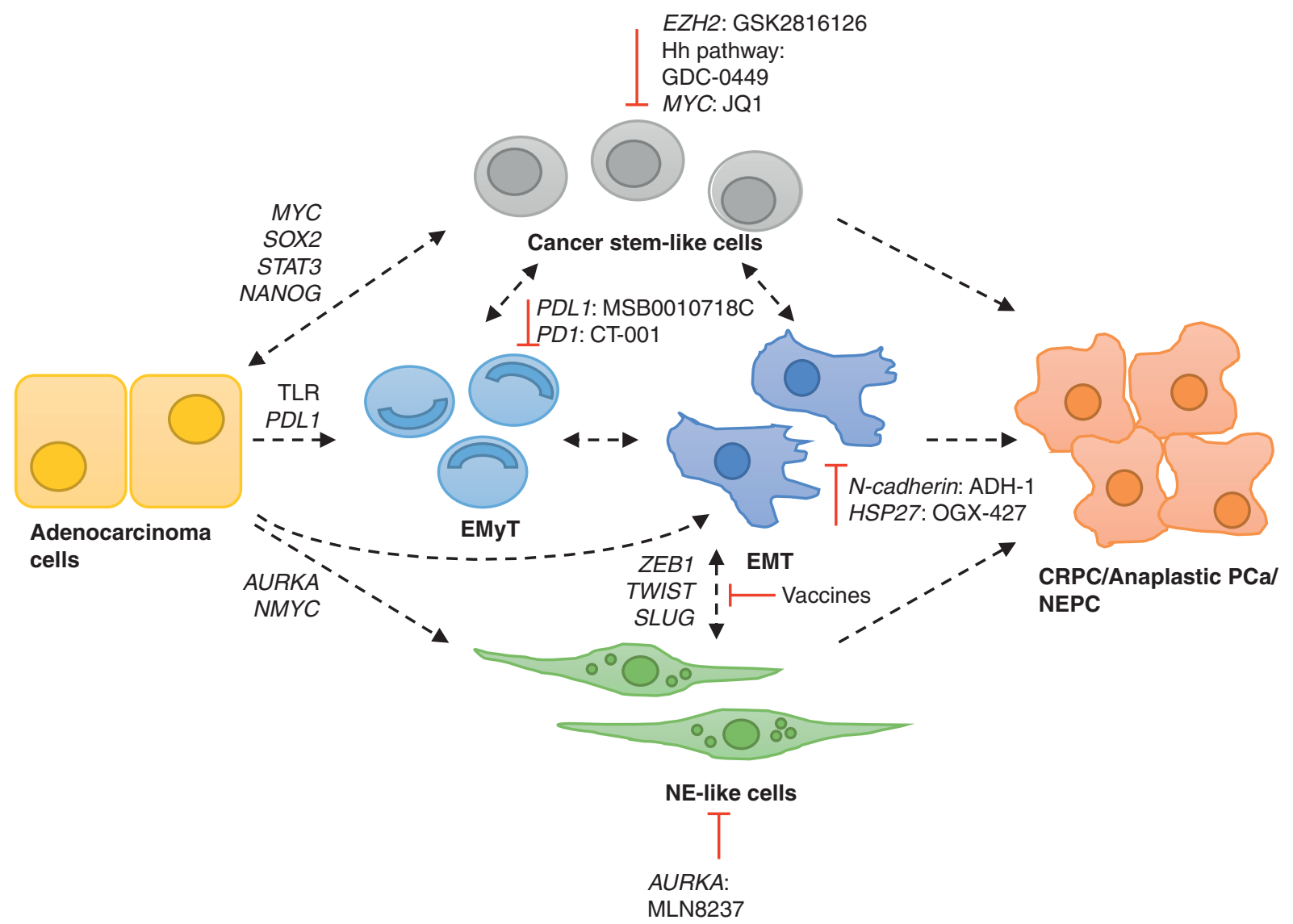

\section{Figure 2}

Targeting tumor cell plasticity in prostate cancer. Under the selective pressure of androgen deprivation, adenocarinoma of the prostate may involve heterogeneous populations of tumor cells, including cancer stemlike cells, cells undergoing epithelial-to-mesenchymal (EMT) or myeloid transition (EMyT), and neuroendocrine-like (NE) like cells. These cell types are interrelated, and the phenotypes may be dynamic, thereby underlying the phenotypic plasticity of tumor cells that have become therapy resistant. Strong evidence suggests that each cell type or plasticity between cell types contributes to prostate cancer progression to CRPC or anaplastic/NEPC. Therapies that target the mechanistic drivers of cellular plasticity and are currently under preclinical and clinical development are highlighted. 
currently in clinical trials, may be a potential means of targeting the $\beta$-catenin/SLUG and STAT3/TWIST signaling pathways in PCa, and it could thus inhibit EMT (Shiota et al. 2013, Cordonnier et al. 2015). TWIST can also be targeted using the $P K C$ inhibitor Ro31-8220, which reduces TWIST signaling and the viability of LNCaP and castration-resistant C4-2 and 22Rv1 cells in combination with anti-androgen enzalutamide (Shiota et al. 2014). Interestingly, TWIST may also be a viable immunotherapy target; recently TWIST was shown to be a TAA in the TRAMP-C2 subcutaneous model of murine PCa, and combined treatment of TRAMP-C2 xenografts in vivo with enzalutamide and a TWIST-specific vaccine significantly reduced tumor burden (Ardiani et al. 2013). Similarly, the T-box transcription factor Brachyury, which drives EMT in many cancers (Fernando et al. 2010), has been identified as another PCa TAA, and yeast-based Brachyury vaccines are currently in development for the treatment of CRPC (Hamilton et al. 2013). In addition, targeted therapies are in development to prevent identified drivers of NEPC and checkpoint molecule expression by tumors. These include aurora kinase and somatostatin inhibitors as well as PDL1 and PD1 monoclonal antibodies. Table 1 presents a list of agents that target cellular plasticity in PCa and other tumor types.

Although we have divided these agents by their ability to modulate a particular plasticity state, like CSCs, cells undergoing EMT, or NEPC, it is clear from the ubiquitous signaling pathways they affect that these inhibitors most likely have the benefit of targeting multiple cell populations. This is underscored by the significant overlap between plastic CRPC cell phenotypes and the intimate relationships between the AR-controlled plasticity pathways. For example, the importance of ARV7 in driving therapy resistance has recently been reported (Antonarakis et al. 2014); thus, targeting variants with novel therapies such as Epi-001 (Myung et al. 2013, Martin et al. 2014) and BR-DIM have gained considerable momentum. Although the goal of these therapies would be to prevent ligandindependent AR activity, which drives the growth and proliferation of AR variant-expressing tumors, the ability of AR variants to drive EMT may suggest that these inhibitors can prevent metastases or reduce CSCs. Indeed, BR-DIM has been shown to inhibit both AR variants and stem cell and EMT markers in PCa (Kong et al. 2015). In addition, although the use of bromodomain inhibitors, such as JQ1, clearly have shown efficacy in reducing AR activity (Asangani et al. 2014), the close association between BRD4 and the genes that control stem cell properties and NEPC, such as MYC (Di Micco et al. 2014,
Rodriguez et al. 2014), may mean that bromodomain inhibitors could simultaneously prevent AR signaling and the emergence of cell types that are associated with a loss of AR activity. Importantly however, we are unaware of any potential adverse side effects that targeting multiple tumor cell populations may have, such as putting strong selective pressure on various signaling pathways, which could lead to emergent mechanisms of resistance.

\section{Conclusion}

Overall, heterogeneous cell populations in tumors dictate the severity of disease by playing different roles in response to anticancer therapies, regeneration and proliferation, metastasis, and immune modulation. In PCa, AR expression and activity regulates CSCs, EMT, EmyT, and transdifferentiation to NEPC, and thus novel $\mathrm{AR}$ targeting agents may inhibit $\mathrm{AR}$ functioning as a central driver of tumor cell phenotypic plasticity. Furthermore, combined approaches that target the AR as well as individual CSC, NEPC, EMT, or immune evasion modulators will most certainly play a role in the treatment landscape of CRPC in the future. With the mounting evidence about the molecular mechanisms that underlie how different cell types emerge during CRPC and therapeutic resistance, and with the significant number of novel agents directed against these mechanisms that are currently in preclinical and clinical phases of development, we may be able to eliminate unique and aggressive PCa tumor cells to prolong survival in CRPC patients (Fig. 2).

\section{Declaration of interest}

The authors declare that there is no conflict of interest that could be perceived as prejudicing the impartiality of this review.

\section{Funding}

This work was supported by the Prostate Cancer Canada and was proudly funded by the Movember Foundation (grant number T2013-01). In addition, JB was supported by a Prostate Cancer Foundation Young Investigator Award.

\section{References}

Acevedo VD, Gangula RD, Freeman KW, Li R, Zhang Y, Wang F, Ayala GE, Peterson LE, Ittmann M \& Spencer DM 2007 Inducible FGFR-1 activation leads to irreversible prostate adenocarcinoma and an epithelial-to-mesenchymal transition. Cancer Cell 12 559-571. (doi:10.1016/j.ccr.2007.11.004)

Published by Bioscientifica Ltd 
Al-Hajj M, Wicha MS, Benito-Hernandez A, Morrison SJ \& Clarke MF 2003 Prospective identification of tumorigenic breast cancer cells. PNAS $\mathbf{1 0 0}$ 3983-3988. (doi:10.1073/pnas.0530291100)

Anose BM, LaGoo L \& Schwendinger J 2008 Characterization of androgen regulation of ZEB-1 and PSA in 22RV1 prostate cancer cells. Advances in Experimental Medicine and Biology 617 541-546. (doi:10.1007/978-0387-69080-3_55)

Antonarakis ES, Lu C, Wang H, Luber B, Nakazawa M, Roeser JC, Chen Y, Mohammad TA, Fedor HL, Lotan TL et al. 2014 AR-V7 and resistance to enzalutamide and abiraterone in prostate cancer. New England Journal of Medicine 371 1028-1038. (doi:10.1056/NEJMoa1315815)

Aparicio A, Logothetis CJ \& Maity SN 2011 Understanding the lethal variant of prostate cancer: power of examining extremes. Cancer Discovery 1 466-468. (doi:10.1158/2159-8290.CD-11-0259)

Ardiani A, Farsaci B, Rogers CJ, Protter A, Guo Z, King TH, Apelian D \& Hodge JW 2013 Combination therapy with a second-generation androgen receptor antagonist and a metastasis vaccine improves survival in a spontaneous prostate cancer model. Clinical Cancer Research 19 6205-6218. (doi:10.1158/1078-0432.CCR-13-1026)

Asangani IA, Dommeti VL, Wang X, Malik R, Cieslik M, Yang R, EscaraWilke J, Wilder-Romans K, Dhanireddy S, Engelke C et al. 2014 Therapeutic targeting of BET bromodomain proteins in castrationresistant prostate cancer. Nature 510 278-282. (doi:10.1038/ nature13229)

Azuma T, Yao S, Zhu G, Flies AS, Flies SJ \& Chen L 2008 B7-H1 is a ubiquitous antiapoptotic receptor on cancer cells. Blood $\mathbf{1 1 1}$ 3635-3643. (doi:10.1182/blood-2007-11-123141)

Baritaki S, Chapman A, Yeung K, Spandidos DA, Palladino M \& Bonavida B 2009 Inhibition of epithelial to mesenchymal transition in metastatic prostate cancer cells by the novel proteasome inhibitor, NPI-0052: pivotal roles of Snail repression and RKIP induction. Oncogene $\mathbf{2 8}$ 3573-3585. (doi:10.1038/onc.2009.214)

Beer TM \& Tombal B 2014 Enzalutamide in metastatic prostate cancer before chemotherapy. New England Journal of Medicine 371 1755-1756. (doi:10.1056/NEJMoa1405095)

Beltran H, Rickman DS, Park K, Chae SS, Sboner A, MacDonald TY, Wang Y, Sheikh KL, Terry S, Tagawa ST et al. 2011 Molecular characterization of neuroendocrine prostate cancer and identification of new drug targets. Cancer Discovery 1 487-495. (doi:10.1158/2159-8290.CD-11-0130)

Bishop JL, Sio A, Angeles A, Roberts ME, Azad AA, Chi KN \& Zoubeidi A 2015 PD-L1 is highly expressed in enzalutamide resistant prostate cancer. Oncotarget 6 234-242.

Bisson I \& Prowse DM 2009 WNT signaling regulates self-renewal and differentiation of prostate cancer cells with stem cell characteristics. Cell Research 19 683-697. (doi:10.1038/cr.2009.43)

Bonnet D \& Dick JE 1997 Human acute myeloid leukemia is organized as a hierarchy that originates from a primitive hematopoietic cell. Nature Medicine 3 730-737. (doi:10.1038/nm0797-730)

de Bono JS, Logothetis CJ, Molina A, Fizazi K, North S, Chu L, Chi KN, Jones RJ, Goodman OB Jr, Saad F et al. 2011 Abiraterone and increased survival in metastatic prostate cancer. New England Journal of Medicine 364 1995-2005. (doi:10.1056/NEJMoa1014618)

Brahmer JR, Drake CG, Wollner I, Powderly JD, Picus J, Sharfman WH, Stankevich E, Pons A, Salay TM, McMiller TL et al. 2010 Phase I study of single-agent anti-programmed death-1 (MDX-1106) in refractory solid tumors: safety, clinical activity, pharmacodynamics, and immunologic correlates. Journal of Clinical Oncology 28 3167-3175. (doi:10.1200/JCO. 2009.26.7609)

Cai X, Dai Z, Reeves RS, Caballero-Benitez A, Duran KL, Delrow JJ, Porter PL, Spies T \& Groh V 2014 Autonomous stimulation of cancer cell plasticity by the human NKG2D lymphocyte receptor coexpressed with its ligands on cancer cells. PLoS ONE 9 e108942. (doi:10.1371/journal.pone.0108942)

Chaffer CL, Brueckmann I, Scheel C, Kaestli AJ, Wiggins PA, Rodrigues LO, Brooks M, Reinhardt F, Su Y, Polyak K et al. 2011 Normal and neoplastic nonstem cells can spontaneously convert to a stem-like state. PNAS 108 7950-7955. (doi:10.1073/pnas.1102454108)
Chaffer CL, Marjanovic ND, Lee T, Bell G, Kleer CG, Reinhardt F, D'Alessio AC, Young RA \& Weinberg RA 2013 Poised chromatin at the ZEB1 promoter enables breast cancer cell plasticity and enhances tumorigenicity. Cell 154 61-74. (doi:10.1016/j.cell.2013.06.005)

Chang CY, Hsuuw YD, Huang FJ, Shyr CR, Chang SY, Huang CK, Kang HY \& Huang KE 2006 Androgenic and antiandrogenic effects and expression of androgen receptor in mouse embryonic stem cells. Fertility and Sterility 85 (Suppl 1) 1195-1203. (doi:10.1016/j.fertnstert. 2005.11.031)

Chen J, Li Y, Yu TS, McKay RM, Burns DK, Kernie SG \& Parada LF 2012 A restricted cell population propagates glioblastoma growth after chemotherapy. Nature 488 522-526. (doi:10.1038/nature11287)

Civenni G, Malek A, Albino D, Garcia-Escudero R, Napoli S, Di Marco S, Pinton S, Sarti M, Carbone GM \& Catapano CV 2013 RNAi-mediated silencing of Myc transcription inhibits stem-like cell maintenance and tumorigenicity in prostate cancer. Cancer Research 73 6816-6827. (doi:10.1158/0008-5472.CAN-13-0615)

Clyne M 2012 Prostate cancer: androgen deprivation causes EMT in the prostate. Nature Reviews. Urology 9 4. (doi:10.1038/nrurol.2011.208)

Collins AT, Berry PA, Hyde C, Stower MJ \& Maitland NJ 2005 Prospective identification of tumorigenic prostate cancer stem cells. Cancer Research 65 10946-10951. (doi:10.1158/0008-5472.CAN-05-2018)

Cordonnier T, Bishop JL, Shiota M, Nip KM, Thaper D, Vahid S, Heroux D, Gleave M \& Zoubeidi A 2015 Hsp27 regulates EGF/ $\beta$-catenin mediated epithelial to mesenchymal transition in prostate cancer. International Journal of Cancer 136 E496-E507. (doi:10.1002/ijc.29122)

Cox ME, Deeble PD, Bissonette EA \& Parsons SJ 2000 Activated $3^{\prime}, 5^{\prime}$-cyclic AMP-dependent protein kinase is sufficient to induce neuroendocrinelike differentiation of the LNCaP prostate tumor cell line. Journal of Biological Chemistry 275 13812-13818. (doi:10.1074/jbc.275.18.13812)

Crea F, Hurt EM, Mathews LA, Cabarcas SM, Sun L, Marquez VE, Danesi R \& Farrar WL 2011 Pharmacologic disruption of Polycomb Repressive Complex 2 inhibits tumorigenicity and tumor progression in prostate cancer. Molecular Cancer 10 40. (doi:10.1186/1476-4598-10-40)

Debes JD, Comuzzi B, Schmidt LJ, Dehm SM, Culig Z \& Tindall DJ 2005 p300 regulates androgen receptor-independent expression of prostatespecific antigen in prostate cancer cells treated chronically with interleukin-6. Cancer Research 65 5965-5973. (doi:10.1158/0008-5472. CAN-04-2837)

Dehm SM, Schmidt LJ, Heemers HV, Vessella RL \& Tindall DJ 2008 Splicing of a novel androgen receptor exon generates a constitutively active androgen receptor that mediates prostate cancer therapy resistance. Cancer Research 68 5469-5477. (doi:10.1158/0008-5472.CAN-08-0594)

Dhodapkar KM, Gettinger SN, Das R, Zebroski H \& Dhodapkar MV 2013 SOX2-specific adaptive immunity and response to immunotherapy in non-small cell lung cancer. Oncoimmunology 2 e25205. (doi:10.4161/ onci.25205)

Di Micco R, Fontanals-Cirera B, Low V, Ntziachristos P, Yuen SK, Lovell CD, Dolgalev I, Yonekubo Y, Zhang G, Rusinova E et al. 2014 Control of embryonic stem cell identity by BRD4-dependent transcriptional elongation of super-enhancer-associated pluripotency genes. Cell Reports 9 234-247. (doi:10.1016/j.celrep.2014.08.055)

Domingo-Domenech J, Vidal SJ, Rodriguez-Bravo V, Castillo-Martin M, Quinn SA, Rodriguez-Barrueco R, Bonal DM, Charytonowicz E, Gladoun N, de la Iglesia-Vicente J et al. 2012 Suppression of acquired docetaxel resistance in prostate cancer through depletion of notch- and hedgehog-dependent tumor-initiating cells. Cancer Cell 22 373-388. (doi:10.1016/j.ccr.2012.07.016)

Driessens G, Beck B, Caauwe A, Simons BD \& Blanpain C 2012 Defining the mode of tumour growth by clonal analysis. Nature 488 527-530. (doi:10.1038/nature11344)

Dubrovska A, Kim S, Salamone RJ, Walker JR, Maira SM, Garcia-Echeverria C, Schultz PG \& Reddy VA 2009 The role of PTEN/Akt/PI3K signaling in the maintenance and viability of prostate cancer stem-like cell populations. PNAS 106 268-273. (doi:10.1073/pnas.0810956106) 
Epstein JI, Amin MB, Beltran H, Lotan TL, Mosquera JM, Reuter VE, Robinson BD, Troncoso P \& Rubin MA 2014 Proposed morphologic classification of prostate cancer with neuroendocrine differentiation. American Journal of Surgical Pathology 38 756-767. (doi:10.1097/PAS 0000000000000208)

Fernando RI, Litzinger M, Trono P, Hamilton DH, Schlom J \& Palena C 2010 The T-box transcription factor Brachyury promotes epithelialmesenchymal transition in human tumor cells. Journal of Clinical Investigation 120 533-544. (doi:10.1172/JCI38379)

Flavahan WA, Wu Q, Hitomi M, Rahim N, Kim Y, Sloan AE, Weil RJ, Nakano I, Sarkaria JN, Stringer BW et al. 2013 Brain tumor initiating cells adapt to restricted nutrition through preferential glucose uptake. Nature Neuroscience 16 1373-1382. (doi:10.1038/nn.3510)

Foulkes WD, Smith IE \& Reis-Filho JS 2010 Triple-negative breast cancer. New England Journal of Medicine 363 1938-1948. (doi:10.1056/ NEJMra1001389)

Fujimoto N, Miyamoto H, Mizokami A, Harada S, Nomura M, Ueta Y, Sasaguri T \& Matsumoto T 2007 Prostate cancer cells increase androgen sensitivity by increase in nuclear androgen receptor and androgen receptor coactivators; a possible mechanism of hormone-resistance of prostate cancer cells. Cancer Investigation 25 32-37. (doi:10.1080/ 07357900601130698)

Germann M, Wetterwald A, Guzman-Ramirez N, van der Pluijm G, Culig Z, Cecchini MG, Williams ED \& Thalmann GN 2012 Stem-like cells with luminal progenitor phenotype survive castration in human prostate cancer. Stem Cells 30 1076-1086. (doi:10.1002/stem.1087)

Goldstein AS, Huang J, Guo C, Garraway IP \& Witte ON 2010 Identification of a cell of origin for human prostate cancer. Science 329 568-571. (doi:10.1126/science.1189992)

Gonzalez-Reyes S, Fernandez JM, Gonzalez LO, Aguirre A, Suarez A, Gonzalez JM, Escaff S \& Vizoso FJ 2011 Study of TLR3, TLR4, and TLR9 in prostate carcinomas and their association with biochemical recurrence. Cancer Immunology, Immunotherapy: CII 60 217-226. (doi:10.1007/s00262-010-0931-0)

Gowda PS, Deng JD, Mishra S, Bandyopadhyay A, Liang S, Lin S, Mahalingam D \& Sun LZ 2013 Inhibition of hedgehog and androgen receptor signaling pathways produced synergistic suppression of castration-resistant prostate cancer progression. Molecular Cancer Research 11 1448-1461. (doi:10.1158/1541-7786.MCR-13-0278)

Gu G, Yuan J, Wills M \& Kasper S 2007 Prostate cancer cells with stem cell characteristics reconstitute the original human tumor in vivo. Cancer Research 67 4807-4815. (doi:10.1158/0008-5472.CAN-06-4608)

Gupta PB, Fillmore CM, Jiang G, Shapira SD, Tao K, Kuperwasser C \& Lander ES 2011 Stochastic state transitions give rise to phenotypic equilibrium in populations of cancer cells. Cell 146 633-644. (doi:10.1016/j.cell.2011.07.026)

Gure AO, Stockert E, Scanlan MJ, Keresztes RS, Jager D, Altorki NK, Old LJ \& Chen YT 2000 Serological identification of embryonic neural proteins as highly immunogenic tumor antigens in small cell lung cancer. PNAS 97 4198-4203. (doi:10.1073/pnas.97.8.4198)

Hamilton DH, Litzinger MT, Jales A, Huang B, Fernando RI, Hodge JW, Ardiani A, Apelian D, Schlom J \& Palena C 2013 Immunological targeting of tumor cells undergoing an epithelial-mesenchymal transition via a recombinant brachyury-yeast vaccine. Oncotarget 4 1777-1790.

Heidenreich A, Bastian PJ, Bellmunt J, Bolla M, Joniau S, van der Kwast T, Mason M, Matveev V, Wiegel T, Zattoni F et al. 2014 EAU guidelines on prostate cancer. Part II: treatment of advanced, relapsing, and castration-resistant prostate cancer. European Urology 65 467-479. (doi:10.1016/j.eururo.2013.11.002)

Hellsten R, Johansson M, Dahlman A, Sterner O \& Bjartell A 2011 Galiellalactone inhibits stem cell-like ALDH-positive prostate cancer cells. PLoS ONE 6 e22118. (doi:10.1371/journal.pone.0022118)

Hoogland AM, Verhoef EI, Roobol MJ, Schroder FH, Wildhagen MF, van der Kwast TH, Jenster G \& van Leenders GJ 2014 Validation of stem cell markers in clinical prostate cancer: $\alpha 6$-integrin is predictive for nonaggressive disease. Prostate 74 488-496. (doi:10.1002/pros.22768) Hurt EM, Kawasaki BT, Klarmann GJ, Thomas SB \& Farrar WL 2008 CD44+ CD24(-) prostate cells are early cancer progenitor/stem cells that provide a model for patients with poor prognosis. British Journal of Cancer 98 756-765. (doi:10.1038/sj.bjc.6604242)

Izumi K, Fang LY, Mizokami A, Namiki M, Li L, Lin WJ \& Chang C 2013 Targeting the androgen receptor with siRNA promotes prostate cancer metastasis through enhanced macrophage recruitment via CCL2/CCR2-induced STAT3 activation. EMBO Molecular Medicine 5 1383-1401. (doi:10.1002/emmm.201202367)

Jacob S, Nayak S, Fernandes G, Barai RS, Menon S, Chaudhari UK, Kholkute SD \& Sachdeva G 2014 Androgen receptor as a regulator of ZEB2 expression and its implications in epithelial-to-mesenchymal transition in prostate cancer. Endocrine-Related Cancer 21 473-486. (doi:10.1530/ERC-13-0514)

Jennbacken K, Tesan T, Wang W, Gustavsson H, Damber JE \& Welen K $2010 \mathrm{~N}$-cadherin increases after androgen deprivation and is associated with metastasis in prostate cancer. Endocrine-Related Cancer 17 469-479. (doi:10.1677/ERC-10-0015)

Jeter CR, Liu B, Liu X, Chen X, Liu C, Calhoun-Davis T, Repass J, Zaehres H, Shen JJ \& Tang DG 2011 NANOG promotes cancer stem cell characteristics and prostate cancer resistance to androgen deprivation. Oncogene 30 3833-3845. (doi:10.1038/onc.2011.114)

Ji J, Judkowski VA, Liu G, Wang H, Bunying A, Li Z, Xu M, Bender J, Pinilla C \& Yu JS 2014 Identification of novel human leukocyte antigen-A*0201-restricted, cytotoxic T lymphocyte epitopes on CD133 for cancer stem cell immunotherapy. Stem Cells Translational Medicine $\mathbf{3}$ 356-364. (doi:10.5966/sctm.2013-0135)

Joseph JD, Lu N, Qian J, Sensintaffar J, Shao G, Brigham D, Moon M, Maneval EC, Chen I, Darimont B et al. 2013 A clinically relevant androgen receptor mutation confers resistance to second-generation antiandrogens enzalutamide and ARN-509. Cancer Discovery 3 1020-1029. (doi:10.1158/2159-8290.CD-13-0226)

Kalluri R \& Weinberg RA 2009 The basics of epithelial-mesenchymal transition. Journal of Clinical Investigation 119 1420-1428. (doi:10.1172/ JCI39104)

Kani K, Malihi PD, Jiang Y, Wang H, Wang Y, Ruderman DL, Agus DB, Mallick P \& Gross ME 2013 Anterior gradient 2 (AGR2): blood-based biomarker elevated in metastatic prostate cancer associated with the neuroendocrine phenotype. Prostate 73 306-315. (doi:10.1002/pros. 22569)

Karhadkar SS, Bova GS, Abdallah N, Dhara S, Gardner D, Maitra A, Isaacs JT, Berman DM \& Beachy PA 2004 Hedgehog signalling in prostate regeneration, neoplasia and metastasis. Nature 431 707-712. (doi:10.1038/nature02962)

Karthaus WR, Iaquinta PJ, Drost J, Gracanin A, van Boxtel R, Wongvipat J, Dowling CM, Gao D, Begthel H, Sachs N et al. 2014 Identification of multipotent luminal progenitor cells in human prostate organoid cultures. Cell 159 163-175. (doi:10.1016/j.cell.2014.08.017)

Kim E, Kim M, Woo DH, Shin Y, Shin J, Chang N, Oh YT, Kim H, Rheey J, Nakano I et al. 2013 Phosphorylation of EZH2 activates STAT3 signaling via STAT3 methylation and promotes tumorigenicity of glioblastoma stem-like cells. Cancer Cell 23 839-852. (doi:10.1016/j.ccr.2013.04.008)

Kim J, Wu L, Zhao JC, Jin HJ \& Yu J 2014 TMPRSS2-ERG gene fusions induce prostate tumorigenesis by modulating microRNA miR-200c. Oncogene 33 5183-5192. (doi:10.1038/onc.2013.461)

Kong D, Banerjee S, Ahmad A, Li Y, Wang Z, Sethi S \& Sarkar FH 2010 Epithelial to mesenchymal transition is mechanistically linked with stem cell signatures in prostate cancer cells. PLOS ONE 5 e12445. (doi:10.1371/journal.pone.0012445)

Kong D, Sethi S, Li Y, Chen W, Sakr WA, Heath E \& Sarkar FH 2015 Androgen receptor splice variants contribute to prostate cancer aggressiveness through induction of EMT and expression of stem cell marker genes. Prostate 75 161-174. (doi:10.1002/pros.22901) 
Korkaya H, Kim GI, Davis A, Malik F, Henry NL, Ithimakin S, Quraishi AA, Tawakkol N, D'Angelo R, Paulson AK et al. 2012 Activation of an IL6 inflammatory loop mediates trastuzumab resistance in HER2 + breast cancer by expanding the cancer stem cell population. Molecular Cell $\mathbf{4 7}$ 570-584. (doi:10.1016/j.molcel.2012.06.014)

Kregel S, Kiriluk KJ, Rosen AM, Cai Y, Reyes EE, Otto KB, Tom W, Paner GP, Szmulewitz RZ \& Vander Griend DJ 2013 Sox2 is an androgen receptorrepressed gene that promotes castration-resistant prostate cancer. PLoS ONE 8 e53701. (doi:10.1371/journal.pone.0053701)

Kregel S, Szmulewitz RZ \& Vander Griend DJ 2014 The pluripotency factor Nanog is directly upregulated by the androgen receptor in prostate cancer cells. Prostate 74 1530-1543. (doi:10.1002/pros.22870)

Kroon P, Berry PA, Stower MJ, Rodrigues G, Mann VM, Simms M, Bhasin D, Chettiar S, Li C, Li PK et al. 2013 JAK-STAT blockade inhibits tumor initiation and clonogenic recovery of prostate cancer stem-like cells. Cancer Research 73 5288-5298. (doi:10.1158/0008-5472.CAN-13-0874)

Lai JJ, Lai KP, Chuang KH, Chang P, Yu IC, Lin WJ \& Chang C 2009 Monocyte/macrophage androgen receptor suppresses cutaneous wound healing in mice by enhancing local TNF- $\alpha$ expression. Journal of Clinical Investigation 119 3739-3751. (doi:10.1172/JCI39335)

Lapuk AV, Wu C, Wyatt AW, McPherson A, McConeghy BJ, Brahmbhatt S, Mo F, Zoubeidi A, Anderson S, Bell RH et al. 2012 From sequence to molecular pathology, and a mechanism driving the neuroendocrine phenotype in prostate cancer. Journal of Pathology 227 286-297. (doi:10.1002/path.4047)

Lee YC, Cheng CJ, Huang M, Bilen MA, Ye X, Navone NM, Chu K, Kao HH, Yu-Lee LY, Wang Z et al. 2010 Androgen depletion up-regulates cadherin-11 expression in prostate cancer. Journal of Pathology 221 68-76. (doi:10.1002/path.2687)

Lee SO, Ma Z, Yeh CR, Luo J, Lin TH, Lai KP, Yamashita S, Liang L, Tian J, Li L et al. 2013a New therapy targeting differential androgen receptor signaling in prostate cancer stem/progenitor vs. non-stem/progenitor cells. Journal of Molecular Cell Biology 5 14-26. (doi:10.1093/jmcb/ mjs042)

Lee YC, Bilen MA, Yu G, Lin SC, Huang CF, Ortiz A, Cho H, Song JH, Satcher RL, Kuang J et al. $2013 b$ Inhibition of cell adhesion by a cadherin-11 antibody thwarts bone metastasis. Molecular Cancer Research 11 1401-1411. (doi:10.1158/1541-7786.MCR-13-0108)

van Leenders G, Dijkman H, Hulsbergen-van de Kaa C, Ruiter D \& Schalken J 2000 Demonstration of intermediate cells during human prostate epithelial differentiation in situ and in vitro using triplestaining confocal scanning microscopy. Laboratory Investigation $\mathbf{8 0}$ 1251-1258. (doi:10.1038/labinvest.3780133)

Leshem O, Madar S, Kogan-Sakin I, Kamer I, Goldstein I, Brosh R, Cohen Y, Jacob-Hirsch J, Ehrlich M, Ben-Sasson S et al. 2011 TMPRSS2/ERG promotes epithelial to mesenchymal transition through the ZEB1/ZEB2 axis in a prostate cancer model. PLoS ONE 6 e21650. (doi:10.1371/ journal.pone.0021650)

Li H, Chen X, Calhoun-Davis T, Claypool K \& Tang DG 2008 PC3 human prostate carcinoma cell holoclones contain self-renewing tumorinitiating cells. Cancer Research 68 1820-1825. (doi:10.1158/0008-5472. CAN-07-5878)

Lim J \& Thiery JP 2012 Epithelial-mesenchymal transitions: insights from development. Development 139 3471-3486. (doi:10.1242/dev.071209)

Lin TH, Izumi K, Lee SO, Lin WJ, Yeh S \& Chang C 2013a Anti-androgen receptor ASC-J9 versus anti-androgens MDV3100 (enzalutamide) or Casodex (bicalutamide) leads to opposite effects on prostate cancer metastasis via differential modulation of macrophage infiltration and STAT3-CCL2 signaling. Cell Death \& Disease 4 e764. (doi:10.1038/cddis. 2013.270)

Lin TH, Lee SO, Niu Y, Xu D, Liang L, Li L, Yeh SD, Fujimoto N, Yeh S \& Chang C 2013b Differential androgen deprivation therapies with antiandrogens casodex/bicalutamide or MDV3100/enzalutamide versus anti-androgen receptor ASC-J9 (R) Lead to promotion versus suppression of prostate cancer metastasis. Journal of Biological Chemistry $\mathbf{2 8 8}$ 19359-19369. (doi:10.1074/jbc.M113.477216)
Lin D, Wyatt AW, Xue H, Wang Y, Dong X, Haegert A, Wu R, Brahmbhatt S, Mo F, Jong L et al. 2014 High fidelity patient-derived xenografts for accelerating prostate cancer discovery and drug development. Cancer Research 74 1272-1283. (doi:10.1158/0008-5472.CAN-13-2921-T)

Liu YN, Liu Y, Lee HJ, Hsu YH \& Chen JH 2008 Activated androgen receptor downregulates E-cadherin gene expression and promotes tumor metastasis. Molecular and Cellular Biology 28 7096-7108. (doi:10.1128/ MCB.00449-08)

Locke JA, Guns ES, Lubik AA, Adomat HH, Hendy SC, Wood CA, Ettinger SL, Gleave ME \& Nelson CC 2008 Androgen levels increase by intratumoral de novo steroidogenesis during progression of castration-resistant prostate cancer. Cancer Research 68 6407-6415. (doi:10.1158/00085472.CAN-07-5997)

Logothetis CJ, Gallick GE, Maity SN, Kim J, Aparicio A, Efstathiou E \& Lin SH 2013 Molecular classification of prostate cancer progression: foundation for marker-driven treatment of prostate cancer. Cancer Discovery 3 849-861. (doi:10.1158/2159-8290.CD-12-0460)

Lubik AA, Gunter JH, Hollier BG, Ettinger S, Fazli L, Stylianou N, Hendy SC, Adomat HH, Gleave ME, Pollak M et al. 2013 IGF2 increases de novo steroidogenesis in prostate cancer cells. Endocrine-Related Cancer 20 173-186. (doi:10.1530/ERC-12-0250)

Lundholm M, Schroder M, Nagaeva O, Baranov V, Widmark A, MinchevaNilsson L \& Wikstrom P 2014 Prostate tumor-derived exosomes downregulate NKG2D expression on natural killer cells and CD8+T cells: mechanism of immune evasion. PLOS ONE 9 e108925. (doi:10.1371/ journal.pone.0108925)

Mani SA, Guo W, Liao MJ, Eaton EN, Ayyanan A, Zhou AY, Brooks M, Reinhard F, Zhang CC, Shipitsin M et al. 2008 The epithelialmesenchymal transition generates cells with properties of stem cells. Cell 133 704-715. (doi:10.1016/j.cell.2008.03.027)

Mao CP, Wu T, Song KH \& Kim TW 2014 Immune-mediated tumor evolution: Nanog links the emergence of a stem like cancer cell state and immune evasion. Oncoimmunology 3 e947871. (doi:10.4161/ 21624011.2014.947871)

Margueron R \& Reinberg D 2011 The Polycomb complex PRC2 and its mark in life. Nature 469 343-349. (doi:10.1038/nature09784)

Markert EK, Mizuno H, Vazquez A \& Levine AJ 2011 Molecular classification of prostate cancer using curated expression signatures. PNAS 108 21276-21281. (doi:10.1073/pnas.1117029108)

Martin SK, Banuelos CA, Sadar MD \& Kyprianou N 2014 N-terminal targeting of androgen receptor variant enhances response of castration resistant prostate cancer to taxane chemotherapy. Molecular Oncology 9 628-639. (doi:10.1016/j.molonc.2014.10.014)

Matuszak EA \& Kyprianou N 2011 Androgen regulation of epithelialmesenchymal transition in prostate tumorigenesis. Expert Review of Endocrinology \& Metabolism 6 469-482. (doi:10.1586/eem.11.32)

McKeithen D, Graham T, Chung LW \& Odero-Marah V 2010 Snail transcription factor regulates neuroendocrine differentiation in LNCaP prostate cancer cells. Prostate 70 982-992. (doi:10.1002/pros.21132)

Mittendorf EA, Philips AV, Meric-Bernstam F, Qiao N, Wu Y, Harrington S, Su X, Wang Y, Gonzalez-Angulo AM, Akcakanat A et al. 2014 PD-L1 expression in triple-negative breast cancer. Cancer Immunology Research 2 361-370. (doi:10.1158/2326-6066.CIR-13-0127)

Mulholland DJ, Kobayashi N, Ruscetti M, Zhi A, Tran LM, Huang J, Gleave M \& Wu H 2012 Pten loss and RAS/MAPK activation cooperate to promote EMT and metastasis initiated from prostate cancer stem/progenitor cells. Cancer Research 72 1878-1889. (doi:10.1158/ 0008-5472.CAN-11-3132)

Myung JK, Banuelos CA, Fernandez JG, Mawji NR, Wang J, Tien AH, Yang YC, Tavakoli I, Haile S, Watt K et al. 2013 An androgen receptor N-terminal domain antagonist for treating prostate cancer. Journal of Clinical Investigation 123 2948-2960. (doi:10.1172/JCI66398)

Nadiminty N, Tummala R, Liu C, Yang J, Lou W, Evans CP \& Gao AC 2013 $\mathrm{NF}-\kappa \mathrm{B} 2 / \mathrm{p} 52$ induces resistance to enzalutamide in prostate cancer: role of androgen receptor and its variants. Molecular Cancer Therapeutics 12 1629-1637. (doi:10.1158/1535-7163.MCT-13-0027) 
Nieto MA 2013 Epithelial plasticity: a common theme in embryonic and cancer cells. Science 342 1234850. (doi:10.1126/science.1234850)

Noh KH, Lee YH, Jeon JH, Kang TH, Mao CP, Wu TC \& Kim TW 2012 Cancer vaccination drives Nanog-dependent evolution of tumor cells toward an immune-resistant and stem-like phenotype. Cancer Research 72 1717-1727. (doi:10.1158/0008-5472.CAN-11-3758)

Palchetti S, Starace D, De Cesaris P, Filippini A, Ziparo E \& Riccioli A 2015 Transfected poly (I:C) activates different dsRNA receptors, leading to apoptosis or immunoadjuvant response in androgen-independent prostate cancer cells. Journal of Biological Chemistry 290 5470-5483. (doi:10.1074/jbc.M114.601625)

Park K, Chen Z, MacDonald TY, Siddiqui J, Ye H, Erbersdobler A, Shevchuk MM, Robinson BD, Sanda MG, Chinnaiyan AM et al. 2014 Prostate cancer with Paneth cell-like neuroendocrine differentiation has recognizable histomorphology and harbors AURKA gene amplification. Human Pathology 45 2136-2143. (doi:10.1016/j.humpath.2014.06.008)

Patrawala L, Calhoun T, Schneider-Broussard R, Li H, Bhatia B, Tang S, Reilly JG, Chandra D, Zhou J, Claypool K et al. 2006 Highly purified CD44 + prostate cancer cells from xenograft human tumors are enriched in tumorigenic and metastatic progenitor cells. Oncogene $\mathbf{2 5}$ 1696-1708. (doi:10.1038/sj.onc.1209327)

Peek EM, Song W, Zhang H, Huang J \& Chin AI 2015 Loss of MyD88 leads to more aggressive TRAMP prostate cancer and influences tumor infiltrating lymphocytes. Prostate 75 463-473. (doi:10.1002/pros.22932)

Qin J, Liu X, Laffin B, Chen X, Choy G, Jeter CR, Calhoun-Davis T, Li H, Palapattu GS, Pang S et al. 2012 The PSA (-/lo) prostate cancer cell population harbors self-renewing long-term tumor-propagating cells that resist castration. Cell Stem Cell 10 556-569. (doi:10.1016/j.stem. 2012.03.009)

Rajasekhar VK, Studer L, Gerald W, Socci ND \& Scher HI 2011 Tumourinitiating stem-like cells in human prostate cancer exhibit increased NF-кB signalling. Nature Communications 2 162. (doi:10.1038/ ncomms1159)

Rapa I, Volante M, Migliore C, Farsetti A, Berruti A, Vittorio Scagliotti G, Giordano S \& Papotti M 2013 Human ASH-1 promotes neuroendocrine differentiation in androgen deprivation conditions and interferes with androgen responsiveness in prostate cancer cells. Prostate $\mathbf{7 3}$ 1241-1249. (doi:10.1002/pros.22679)

Rezania S, Amirmozaffari N, Rashidi N, Mirzadegan E, Zarei S, Ghasemi J, Zarei O, Katouzian L \& Zarnani AH 2014 The same and not the same: heterogeneous functional activation of prostate tumor cells by TLR ligation. Cancer Cell International 14 54. (doi:10.1186/1475-2867-14-54)

Robinson DR, Zylstra CR \& Williams BO 2008 Wnt signaling and prostate cancer. Current Drug Targets 9 571-580. (doi:10.2174/ 138945008784911831)

Rocchi P, Beraldi E, Ettinger S, Fazli L, Vessella RL, Nelson C \& Gleave M 2005 Increased Hsp27 after androgen ablation facilitates androgenindependent progression in prostate cancer via signal transducers and activators of transcription 3-mediated suppression of apoptosis. Cancer Research 65 11083-11093. (doi:10.1158/0008-5472.CAN-05-1840)

Rodriguez RM, Suarez-Alvarez B, Salvanes R, Huidobro C, Torano EG, Garcia-Perez JL, Lopez-Larrea C, Fernandez AF, Bueno C, Menendez P et al. 2014 Role of BRD4 in hematopoietic differentiation of embryonic stem cells. Epigenetics 9 566-578. (doi:10.4161/epi.27711)

Rogers EN, Jones DZ, Kidd NC, Yeyeodu S, Brock G, Ragin C, Jackson M, McFarlane-Anderson N, Tulloch-Reid M, Sean Kimbro Ket al. 2013 Tolllike receptor-associated sequence variants and prostate cancer risk among men of African descent. Genes and Immunity 14 347-355. (doi:10.1038/gene.2013.22)

Ryan CJ, Smith MR, de Bono JS, Molina A, Logothetis CJ, de Souza P, Fizazi K, Mainwaring P, Piulats JM, Ng S et al. 2013 Abiraterone in metastatic prostate cancer without previous chemotherapy. New England Journal of Medicine 368 138-148. (doi:10.1056/NEJMoa1209096)

Salvatori L, Caporuscio F, Verdina A, Starace G, Crispi S, Nicotra MR, Russo A, Calogero RA, Morgante E, Natali PG et al. 2012 Cell-to-cell signaling influences the fate of prostate cancer stem cells and their potential to generate more aggressive tumors. PLOS ONE 7 e31467. (doi:10.1371/journal.pone.0031467)

Sauter CN, McDermid RL, Weinberg AL, Greco TL, Xu X, Murdoch FE \& Fritsch MK 2005 Differentiation of murine embryonic stem cells induces progesterone receptor gene expression. Experimental Cell Research 311 251-264. (doi:10.1016/j.yexcr.2005.09.005)

Schalken JA \& van Leenders G 2003 Cellular and molecular biology of the prostate: stem cell biology. Urology 62 11-20. (doi:10.1016/S00904295(03)00758-1)

Scheel C \& Weinberg RA 2012 Cancer stem cells and epithelialmesenchymal transition: concepts and molecular links. Seminars in Cancer Biology 22 396-403. (doi:10.1016/j.semcancer.2012.04.001)

Schepers AG, Snippert HJ, Stange DE, van den Born M, van Es JH, van de Wetering M \& Clevers H 2012 Lineage tracing reveals Lgr5 + stem cell activity in mouse intestinal adenomas. Science 337 730-735. (doi:10.1126/science.1224676)

Schramm HM 2014 Should EMT of cancer cells be understood as epithelialmyeloid transition? Journal of Cancer 5 125-132. (doi:10.7150/jca.8242)

Schroeder A, Herrmann A, Cherryholmes G, Kowolik C, Buettner R, Pal S, Yu H, Muller-Newen G \& Jove R 2014 Loss of androgen receptor expression promotes a stem-like cell phenotype in prostate cancer through STAT3 signaling. Cancer Research 74 1227-1237. (doi:10.1158/ 0008-5472.CAN-13-0594)

Schweizer L, Rizzo CA, Spires TE, Platero JS, Wu Q, Lin TA, Gottardis MM \& Attar RM 2008 The androgen receptor can signal through Wnt/ $\beta$-catenin in prostate cancer cells as an adaptation mechanism to castration levels of androgens. BMC Cell Biology 9 4. (doi:10.1186/ 1471-2121-9-4)

Segrelles C, Garcia-Escudero R, Garin MI, Aranda JF, Hernandez P, Ariza JM, Santos M, Paramio JM \& Lorz C 2014 Akt signaling leads to stem cell activation and promotes tumor development in epidermis. Stem Cells 32 1917-1928. (doi:10.1002/stem.1669)

Seiler D, Zheng J, Liu G, Wang S, Yamashiro J, Reiter RE, Huang J \& Zeng G 2013 Enrichment of putative prostate cancer stem cells after androgen deprivation: upregulation of pluripotency transactivators concurs with resistance to androgen deprivation in LNCaP cell lines. Prostate $\mathbf{7 3}$ 1378-1390. (doi:10.1002/pros.22685)

Shang Z, Cai Q, Zhang M, Zhu S, Ma Y, Sun L, Jiang N, Tian J, Niu X, Chen J et al. 2015 A switch from CD44 + cell to EMT cell drives the metastasis of prostate cancer. Oncotarget 6 1202-1216.

Sharma P \& Allison JP 2015 The future of immune checkpoint therapy. Science 348 56-61. (doi:10.1126/science.aaa8172)

Sharma NL, Massie CE, Ramos-Montoya A, Zecchini V, Scott HE, Lamb AD, MacArthur S, Stark R, Warren AY, Mills IG et al. 2013 The androgen receptor induces a distinct transcriptional program in castrationresistant prostate cancer in man. Cancer Cell 23 35-47. (doi:10.1016/j. ccr.2012.11.010)

Shih J, Rahman M, Luong QT, Lomeli SH, Riss J, Prins RM, Gure AO \& Zeng G 2014 Dominant B-cell epitopes from cancer/stem cell antigen SOX2 recognized by serum samples from cancer patients. American Journal of Clinical and Experimental Immunology 3 84-90.

Shiota M, Yokomizo A, Tada Y, Inokuchi J, Kashiwagi E, Masubuchi D, Eto M, Uchiumi T \& Naito S 2010 Castration resistance of prostate cancer cells caused by castration-induced oxidative stress through Twist1 and androgen receptor overexpression. Oncogene 29 237-250. (doi:10.1038/onc.2009.322)

Shiota M, Bishop JL, Nip KM, Zardan A, Takeuchi A, Cordonnier T, Beraldi E, Bazov J, Fazli L, Chi K et al. 2013 Hsp27 regulates epithelial mesenchymal transition, metastasis, and circulating tumor cells in prostate cancer. Cancer Research 73 3109-3119. (doi:10.1158/00085472.CAN-12-3979)

Shiota M, Yokomizo A, Takeuchi A, Imada K, Kashiwagi E, Song Y, Inokuchi J, Tatsugami K, Uchiumi T \& Naito S 2014 Inhibition of protein kinase C/Twist1 signaling augments anticancer effects of 
androgen deprivation and enzalutamide in prostate cancer. Clinical Cancer Research 20 951-961. (doi:10.1158/1078-0432.CCR-13-1809)

Siegel R, Ma J, Zou Z \& Jemal A 2014 Cancer statistics, 2014. CA: A Cancer Journal for Clinicians 64 9-29. (doi:10.3322/caac.21208)

Soliman H, Khalil F \& Antonia S 2014 PD-L1 expression is increased in a subset of basal type breast cancer cells. PLOS ONE 9 e88557. (doi:10.1371/journal.pone.0088557)

Spiotto MT \& Chung TD 2000 STAT3 mediates IL-6-induced neuroendocrine differentiation in prostate cancer cells. Prostate 42 186-195. (doi:10.1002/(SICI)1097-0045(20000215)42:3 < 186::AID-PROS4 > 3.0. CO;2-E)

Sun Y, Wang BE, Leong KG, Yue P, Li L, Jhunjhunwala S, Chen D, Seo K, Modrusan Z, Gao WQ et al. 2012 Androgen deprivation causes epithelial-mesenchymal transition in the prostate: implications for androgen-deprivation therapy. Cancer Research 72 527-536. (doi:10. 1158/0008-5472.CAN-11-3004)

Sun J, Tao S, Gao Y, Peng T, Tan A, Zhang H, Yang X, Qin X, Hu Y, Feng J et al. 2013 Genome-wide association study identified novel genetic variant on SLC45A3 gene associated with serum levels prostate-specific antigen (PSA) in a Chinese population. Human Genetics 132 423-429. (doi:10.1007/s00439-012-1254-3)

Svensson C, Ceder J, Iglesias-Gato D, Chuan YC, Pang ST, Bjartell A, Martinez RM, Bott L, Helczynski L, Ulmert D et al. 2014 REST mediates androgen receptor actions on gene repression and predicts early recurrence of prostate cancer. Nucleic Acids Research 42 999-1015. (doi:10.1093/nar/gkt921)

Swaminathan SK, Roger E, Toti U, Niu L, Ohlfest JR \& Panyam J 2013 CD133-targeted paclitaxel delivery inhibits local tumor recurrence in a mouse model of breast cancer. Journal of Controlled Release 171 280-287. (doi:10.1016/j.jconrel.2013.07.014)

Tagawa ST 2014 Neuroendocrine prostate cancer after hormonal therapy: knowing is half the battle. Journal of Clinical Oncology 32 3360-3364. (doi:10.1200/JCO.2014.57.5100)

Tan HL, Sood A, Rahimi HA, Wang W, Gupta N, Hicks J, Mosier S, Gocke CD, Epstein JI, Netto GJ et al. 2014 Rb loss is characteristic of prostatic small cell neuroendocrine carcinoma. Clinical Cancer Research 20 890-903. (doi:10.1158/1078-0432.CCR-13-1982)

Tanaka H, Kono E, Tran CP, Miyazaki H, Yamashiro J, Shimomura T, Fazli L, Wada R, Huang J, Vessella RL et al. 2010 Monoclonal antibody targeting of N-cadherin inhibits prostate cancer growth, metastasis and castration resistance. Nature Medicine 16 1414-1420. (doi:10.1038/ $\mathrm{nm} .2236)$

Tang Y, Hamburger AW, Wang L, Khan MA \& Hussain A 2009 Androgen deprivation and stem cell markers in prostate cancers. International Journal of Clinical and Experimental Pathology 3 128-138.

Taube JM, Klein AP, Brahmer JR, Xu H, Pan X, Kim JH, Chen L, Pardoll DM, Topalian SL \& Anders RA 2014 Association of PD-1, PD-1 ligands, and other features of the tumor immune microenvironment with response to anti-PD-1 therapy. Clinical Cancer Research 20 5064-5074. (doi:10.1158/1078-0432.CCR-13-3271)

Taylor RA, Toivanen R, Frydenberg M, Pedersen J, Harewood L, Australian Prostate Cancer Bioresource, Collins AT, Maitland NJ \& Risbridger GP 2012 Human epithelial basal cells are cells of origin of prostate cancer, independent of CD133 status. Stem Cells 30 1087-1096. (doi:10.1002/ stem.1094)

Terry S \& Beltran H 2014 The many faces of neuroendocrine differentiation in prostate cancer progression. Frontiers in Oncology 4 60. (doi:10.3389/ fonc.2014.00060)

Terry S, Maille P, Baaddi H, Kheuang L, Soyeux P, Nicolaiew N, Ceraline J, Firlej V, Beltran H, Allory Y et al. 2013 Cross modulation between the androgen receptor axis and protocadherin-PC in mediating neuroendocrine transdifferentiation and therapeutic resistance of prostate cancer. Neoplasia 15 761-772. (doi:10.1593/neo.122070)

Topalian SL, Hodi FS, Brahmer JR, Gettinger SN, Smith DC, McDermott DF, Powderly JD, Carvajal RD, Sosman JA, Atkins MB et al. 2012 Safety, activity, and immune correlates of anti-PD-1 antibody in cancer.
New England Journal of Medicine 366 2443-2454. (doi:10.1056/ NEJMoa1200690)

Tzelepi V, Zhang J, Lu JF, Kleb B, Wu G, Wan X, Hoang A, Efstathiou E, Sircar K, Navone NM et al. 2012 Modeling a lethal prostate cancer variant with small-cell carcinoma features. Clinical Cancer Research 18 666-677. (doi:10.1158/1078-0432.CCR-11-1867)

Urbanucci A, Sahu B, Seppala J, Larjo A, Latonen LM, Waltering KK, Tammela TL, Vessella RL, Lahdesmaki H, Janne OA et al. 2012 Overexpression of androgen receptor enhances the binding of the receptor to the chromatin in prostate cancer. Oncogene 31 2153-2163. (doi:10.1038/onc.2011.401)

Visakorpi T, Hyytinen E, Koivisto P, Tanner M, Keinanen R, Palmberg C, Palotie A, Tammela T, Isola J \& Kallioniemi OP 1995 In vivo amplification of the androgen receptor gene and progression of human prostate cancer. Nature Genetics 9 401-406. (doi:10.1038/ng0495-401)

Visvader JE \& Lindeman GJ 2008 Cancer stem cells in solid tumours: accumulating evidence and unresolved questions. Nature Reviews. Cancer 8 755-768. (doi:10.1038/nrc2499)

Vlachostergios PJ \& Papandreou CN 2015 Targeting neuroendocrine prostate cancer: molecular and clinical perspectives. Frontiers in Oncology 5 6. (doi:10.3389/fonc.2015.00006)

Vural B, Chen LC, Saip P, Chen YT, Ustuner Z, Gonen M, Simpson AJ, Old LJ, Ozbek U \& Gure AO 2005 Frequency of SOX Group B (SOX 1, 2, 3) and ZIC2 antibodies in Turkish patients with small cell lung carcinoma and their correlation with clinical parameters. Cancer 103 2575-2583. (doi:10.1002/cncr.21088)

Waltering KK, Helenius MA, Sahu B, Manni V, Linja MJ, Janne OA \& Visakorpi T 2009 Increased expression of androgen receptor sensitizes prostate cancer cells to low levels of androgens. Cancer Research 69 8141-8149. (doi:10.1158/0008-5472.CAN-09-0919)

Wang G, Wang J \& Sadar MD 2008 Crosstalk between the androgen receptor and $\beta$-catenin in castrate-resistant prostate cancer. Cancer Research 68 9918-9927. (doi:10.1158/0008-5472.CAN-08-1718)

Wang X, Lee SO, Xia S, Jiang Q, Luo J, Li L, Yeh S \& Chang C 2013 Endothelial cells enhance prostate cancer metastasis via IL-6 $\rightarrow$ androgen receptor $\rightarrow$ TGF- $\beta \rightarrow$ MMP-9 signals. Molecular Cancer Therapeutics 12 1026-1037. (doi:10.1158/1535-7163.MCT-12-0895)

Wang ZA, Toivanen R, Bergren SK, Chambon P \& Shen MM 2014 Luminal cells are favored as the cell of origin for prostate cancer. Cell Reports $\mathbf{8}$ 1339-1346. (doi:10.1016/j.celrep.2014.08.002)

Wei C, Guomin W, Yujun L \& Ruizhe Q 2007 Cancer stem-like cells in human prostate carcinoma cells DU145: the seeds of the cell line? Cancer Biology \& Therapy 6 763-768. (doi:10.4161/cbt.6.5.3996)

Wu K, Gore C, Yang L, Fazli L, Gleave M, Pong RC, Xiao G, Zhang L, Yun EJ, Tseng SF et al. 2012 Slug, a unique androgen-regulated transcription factor, coordinates androgen receptor to facilitate castration resistance in prostate cancer. Molecular Endocrinology 26 1496-1507. (doi:10.1210/ me.2011-1360)

Wyce A, Degenhardt Y, Bai Y, Le B, Korenchuk S, Crouthame MC, McHugh CF, Vessella R, Creasy CL, Tummino PJ et al. 2013 Inhibition of BET bromodomain proteins as a therapeutic approach in prostate cancer. Oncotarget 4 2419-2429.

Xin L, Lawson DA \& Witte ON 2005 The Sca-1 cell surface marker enriches for a prostate-regenerating cell subpopulation that can initiate prostate tumorigenesis. PNAS 102 6942-6947. (doi:10.1073/pnas.0502320102)

Xu K, Wu ZJ, Groner AC, He HH, Cai C, Lis RT, Wu X, Stack EC, Loda M, Liu T et al. $2012 \mathrm{EZH} 2$ oncogenic activity in castration-resistant prostate cancer cells is Polycomb-independent. Science 338 1465-1469. (doi:10.1126/science.1227604)

Yang L, Wang L, Lin HK, Kan PY, Xie S, Tsai MY, Wang PH, Chen YT \& Chang C 2003 Interleukin-6 differentially regulates androgen receptor transactivation via PI3K-Akt, STAT3, and MAPK, three distinct signal pathways in prostate cancer cells. Biochemical and Biophysical Research Communications 305 462-469. (doi:10.1016/S0006-291X(03)00792-7)

Published by Bioscientifica Ltd. 
Yang F, Chen Y, Shen T, Guo D, Dakhova O, Ittmann MM, Creighton CJ, Zhang Y, Dang TD \& Rowley DR 2014 Stromal TGF- $\beta$ signaling induces AR activation in prostate cancer. Oncotarget 5 10854-10869.

Yang X, Lyer AK, Singh A, Choy E, Hornicek FJ, Amiji MM \& Duan Z 2015 MDR1 siRNA loaded hyaluronic acid-based CD44 targeted nanoparticle systems circumvent paclitaxel resistance in ovarian cancer. Scientific Reports 5 8509. (doi:10.1038/srep08509)

Yates C 2011 Prostate tumor cell plasticity: a consequence of the microenvironment. Advances in Experimental Medicine and Biology $\mathbf{7 2 0}$ $81-90$.

Yu J, Yu J, Mani RS, Cao Q, Brenner CJ, Cao X, Wang X, Wu L, Li J, Hu M et al. 2010 An integrated network of androgen receptor, Polycomb, and TMPRSS2-ERG gene fusions in prostate cancer progression. Cancer Cell 17 443-454. (doi:10.1016/j.ccr.2010.03.018)

Zang X, Thompson RH, Al-Ahmadie HA, Serio AM, Reuter VE, Eastham JA, Scardino PT, Sharma P \& Allison JP 2007 B7-H3 and B7x are highly expressed in human prostate cancer and associated with disease spread and poor outcome. PNAS 104 19458-19463. (doi:10.1073/pnas. 0709802104)

Zhao H, Thong A, Nolley R, Reese SW, Santos J, Ingels A \& Peehl DM 2013 Patient-derived tissue slice grafts accurately depict response of high-risk primary prostate cancer to androgen deprivation therapy. Journal of Translational Medicine 11 199. (doi:10.1186/1479-587611-199)

Zhu ML \& Kyprianou N 2010 Role of androgens and the androgen receptor in epithelial-mesenchymal transition and invasion of prostate cancer cells. FASEB Journal 24 769-777. (doi:10.1096/fj.09-136994)

Zhu W, Zhu DS, Madan RA, Gulley JL, Figg WD \& Dahut WL 2010 Treatment of castration-resistant prostate cancer: updates on therapeutics targeting the androgen receptor signaling pathway. American Journal of Therapeutics 17 176-181. (doi:10.1097/MJT. Ob013e3181c6c0b2)

Received in final form 15 April 2015

Accepted 27 April 2015

Made available online as an Accepted Preprint

1 May 2015
Published by Bioscientifica Ltd. 